\title{
THE IMPRINT OF THE GEOLOGICAL INHERITANCE AND PRESENT DYNAMICS ON URUGUAYAN INNER SHELF SEDIMENTS (SOUTH-WESTERN ATLANTIC)
}

\section{Leticia Burone ${ }^{1}$, Paula Franco-Fraguas ${ }^{1}$, Michel Michaelovitch de Mahiques ${ }^{2}$, Nuria

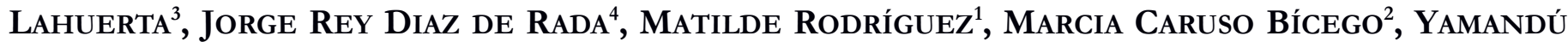 MARÍN $^{1}$, MÓNICA GÓMEZ-ERACHE ${ }^{1}$ AND LEONARDO ORTEGA ${ }^{5}$}

1 Universidad de la República, Facultad de Ciencias - CINCYTEMA - Sección Oceanología, Iguá 4225, Montrevideo 11400, Uruguay

2 Instituto Oceanográfico da Universidade de São Paulo, Praça do Oceanográfico, 191, 05508-120 São Paulo, SP, Brazil

3 University of Wollongong, Northfields Ave, Wollongong NSW 2522, Australia

4 Estudios Geológicos Marinos, S.A. Local PP/L1-05. Puerto de Málaga. 29001. Málaga., España

5 Sección Oceanografía, Departamento de Biología Pesquera, Dirección Nacional de Recursos Acuáticos (DINARA), MGAP, Constituyente 1497, Montevideo, Uruguay

*Corresponding Author, lburone@fcien.edu.uy, lburone@gmail.com

Received on 15 October 2019

Received in revised form on 12 November 2019

Accepted on 15 November 2019

\section{Editor: Maria Virginia Alves Martins, Universidade do Estado do Rio de Janeiro, Brazil}

\section{Abstract}

The Uruguayan continental shelf is characterised by a unique hydrographic system, composed of the Río de la Plata buoyant plume (RdlP-BP), and by water masses of contrasting thermohaline characteristics. Below the RdlP-BP the southward-flowing Subtropical Shelf Water and the northward-flowing Subantarctic Shelf Water converge at the Subtropical Shelf Front, which is the shelf extension of the Brazil-Malvinas Confluence. Three main sedimentary environments can be described associated with; I) "Atlantic coastal sands" (i.e. onshore from the palaeovalley); II) the SW-NE running "RdlP palaeovalley" and; III) "Relict sands" (i.e., offshore of the RdlP palaeovalley). Three exposed sedimentary units (U1 to U3) identified from acoustic profiles and sediment cores (sedimentary characteristics of stratigraphic units) almost entirely restricted to the palaeovalley. The transect here studied intersects these three environments contributing thus with the description of the morphological setting and sedimentary coverture. Physical and geochemical data were integrated and used to characterise the sedimentary facies previously described on the inner shelf and to understand environmental control on the development of these facies. Sediments from U1 show the terrestrial imprint of the RdlP and drier regional conditions, while sediments that characterised U3 indicate a sandy facies (quartz and bioclasts: whole and fragmented shells and polychaetes tubes) corresponding to an ancient coast. This last (with approximately $11 \mathrm{~m}$ height), is probably related to sea-level stabilization, between 20 and $25 \mathrm{~m}$

\section{Citation:}

Burone, L., Franco-Fraguas, P., Mahiques, M.M., Lahuerta, N., Diaz de Rada, J.R. Rodríguez, M., Bícego, M.C., Marín, Y., Gómez-Erache, M., Ortega, L., 2019. The imprint of the geological inheritance and present dynamics on Uruguayan inner shelf sediments (South-Western Atlantic). Journal of Sedimentary Environments, 4 (4): 403-420.

occurring during the Upper Pleistocene and Holocene for the South-Western Atlantic. The sediment from U3 reflects the colder and drier conditions prevailing in the region during the formation of this facies (13.7 and $9.7 \mathrm{cal} \mathrm{ka} \mathrm{BP})$. Eroded sediments (e.g., from U3; ancient coast) are deposited inside the palaeovalley and on the onshore region (between the palaeovalley and coastal sands). Also, U1 extends from the palaeovalley covering the onshore region. The outcrop of warmer oceanic shelf waters was probably a consequence of the geomorphology of the palaeovalley (edge of the palaeovalley) and related to the still fall presence of waters typical of the austral warm season when higher advection of Brazil Current occurs over the shelf. In this regard, the mound-like feature should induce bottom water to rise, operating as a ramp. Productivity proxies ( $\mathrm{Si} / \mathrm{Ti}$, $\mathrm{Ba} / \mathrm{Ti}, \mathrm{Ca} / \mathrm{Ti}$ and $\mathrm{P} / \mathrm{Ti}$ ) present the highest values in these stations (S16-S18), reflecting the imprint of the upwelling in the sediment. The information reported in this work is particularly important to better understand sedimentological dynamics on the Uruguayan inner shelf and the Southwestern Atlantic region. It is also important for elaborating more precise paleoenvironmental and palaeoceanographic reconstructions.

Keywords: Sedimentary dynamics. Hydrographic dynamics. Río de la Plata estuary. South-western Atlantic. Inner shelf. 


\section{Introduction}

Continental shelves evolve from a dynamic process of adaptation to eustatic oscillations. In this sense, waves, tides, currents and fluvial discharge, determine particle dispersion and reworking as well as the construction of sedimentary structures that can be recognised at the Present (i.e. escarpments, terraces and palaeovalleys; Murray-Wallace and Woodroffe, 2014).

Relative sea-level changes in the Quaternary are considered the result of tectono-eustasy, geoidal-eustasy and glacio-eustasy (Murray-Wallace and Woodroffe, 2014). The last is described as the main cause of the morphological evolution of the Uruguayan Continental Margin (UCM; Urien and Martins, 1989; Martins et al., 2003; 2005). Shoreline migration (past sea-level positions) is the more relevant feature associated to marine transgressions and regressions caused by the water volume and global temperature variation (Muto and Steel, 1997; Abreu and Neto 1998).

The UCM is located in a key region as regard to ocean hydrodynamic. It is dominated by the dynamic of the Río de la Plata buoyant plume, the discharge of the second hydrographic basin in South America with $22000 \mathrm{~m}^{3} / \mathrm{s}^{-1}$ (Framiñan and Brown, 1996), and by the convergence of water masses with contrasting hydrographic conditions. This convergence forms the Subtropical Shelf Front and the Brazil-Malvinas convergence in the shelf and deep water, respectively.

Climate of subtropical Atlantic off Uruguay is wet with a marked seasonality that generates a reversal in winds and currents direction on the continental margin. This is consequence of the migration of the high-pressure centre of the South Atlantic. Inter-annual variability is mainly associated with the remote influence of the El Niño phenomenon in the Equatorial Pacific (e.g., Pisciottano et al., 1994; Díaz et al., 1998; Cazes-Boezio et al., 2003). The tropical climate in the north of South America (Brazil) foments the occurrence of water bodies with subtropical characteristics. In the south, the Antarctic climate induces the formation of water masses of Antarctic characteristics (Strub et al., 1998).

Variations of the Southwestern Atlantic marine circulation patterns and of the Sea Surface Temperature (SST) may occur over time scales ranging from sub-seasonal to seasonal and interannual. These variations are strongly influenced by the interactions between the opposite flows of the $\mathrm{BC}$ and the MC, which in turn are affected by the basin wind field and other atmospheric characteristics, such as the South Atlantic Convergence Zone (SACZ; Campos et al., 2008). The UCM is characterised by sediments deposited after the Marine Isotope Stage 5e highstand (Urien and Martins, 1987, 1989; Martins et al., 2003; 2005). These sediments were redistributed and reworked after the beginning of the marine transgression that followed the Last
Glacial Maximum (LGM) (Martins et al., 2003). According to Guilderson et al. (2000), a minimum sea-level of $-150 \mathrm{~m}$ was reached during the LGM. At 17,500 years BP a marine transgression produced an increase in water depth and reduction in coastal processes energy (Corrêa, 1996). The maximum sea-level highstand of $+6.5 \mathrm{~m}$ occurred at $5.6 \mathrm{cal}$ ka BP (Gyllencreutz et al., 2010).

According to Corrêa (1996), during the Holocene there was a hiatus when the mean sea-level decreased (Corrêa, 1996). In addition, there were periods when the rate of sea level rise decreased, allowing sediment deposition and accumulation. Consequently, on the continental shelf of the UCM there are morphological features and sedimentary facies that evidence these sea-level migrations (Urien and Martins, 1989; Martins et al., 2003; 2005; Lantzsch et al., 2014).

Topographical evidence includes; 1) the RdlP palaeovalley, $45 \mathrm{~km}$ wide and $50 \mathrm{~m}$ deep (Lantzsch et al., 2014), distributed along the inner continental shelf and delineated during the LGM, and 2) several ancient coasts distributed throughout the continental shelf formed during deglacial periods (Urien and Martins, 1989; Martins et al., 2003; 2005). Distinct sedimentary facies were recognized along the Atlantic coast (inshore from the palaeovalley), the RdlP palaeovalley itself, and along the middle and outer continental shelf (offshore from the palaeovalley) (Urien et al., 1980a, b; Martins and Martins, 2004; Cavallotto et al., 2005; Burone et al., 2013; Lantzsch et al., 2014). Even though these differential distributions along the UCM have been known of since the 1980s (Urien et al., 1980a, b; Martins et al., 2003), the detailed location, distribution, and characteristics of both geomorphological features and sedimentary facies are still unknown (Burone, et al., 2014; 2018). Recently, several studies have made significant contributions regarding the geomorphological characteristics and sedimentary facies along the shelf (Burone et al., 2013; Lantzsch et al., 2014; Pérez et al., 2018).

For stratigraphic units (U4 to U1) were identified from acoustic profiles and sediment cores by Lantzsch et al. (2014). They are almost entirely restricted to the palaeovalley and three of them are exposed (U3 to U1; see Fig. 1). However, detailed studies linking hydrodynamics, geomorphology and modern sedimentary processes in the UCM are still very scarce, especially regarding the inner continental shelf. In this complex region there is a knowledge gap concerning the environmental dynamic linking the sedimentary environments, the geochemical characterisation of these environments and the role of the geomorphological features on the hydrological and sedimentological system.

In this regard, it is important to point out that the geochemical composition and distribution of surface marine sediments reflects modern and past sedimentary processes. 
Source rocks and circulation regimes can be evaluated by analysing element ratios (i.e., $\mathrm{Al} / \mathrm{Si}$ ) which can assist in the identification of the sediments origin because these ratios reflect the climatic conditions of the continental parent rocks (Weltje and Tjallingii, 2008). Ti/Al can be used as a proxy for aeolian versus fluvial input in regions of dust deposition. In marine sediments, the coarse sediment fractions are enriched in Ti (Schütz and Rahn, 1982; Shiller, 1982; Govin et al., 2012), while $\mathrm{Al}$ is mostly associated with fine-particle clay minerals (Biscaye, 1965). In this regard, $\mathrm{Ti} / \mathrm{Al}$ values can be correlated with grain size, and hence show fluctuations in trade wind and aeolian supply.

Also, the contents and distributions of minor $(\mathrm{Ba})$ and major (i.e., $\mathrm{Si}$, Ti, $\mathrm{Fe}, \mathrm{Al}, \mathrm{K}, \mathrm{Mn}, \mathrm{Ca}, \mathrm{P}$ and $\mathrm{Mg}$ ) elements provide additional information concerning marine depositional settings (Martin and Meybeck, 1979; Murray et al., 1995; Shumilin et al., 2002; Lim et al., 2006; Yang and Youn, 2007; Burone et al., 2013), including both qualitative and quantitative aspects of biological production and the mineralogical and textural characteristics of the sediment particles. The analysis of the marine versus terrestrial origins of organic matter can be inferred from stable isotopes of carbon and nitrogen and elemental $\mathrm{C} / \mathrm{N}$ ratios (Prahl et al., 1994; Mahiques et al., 1999; Burone et al., 2013; FrancoFraguas et al., 2016).

Therefore, considering the close relationship between hydrology, geomorphology and sedimentation, knowledge of modern depositional environments is a crucial element in understanding both current and past regional hydrology as well as climatic conditions. Thus, the main goal of this study is to identify and discuss the imprint of the geological inheritance and the interplay with present sedimentary and hydrographic dynamics on the inner Uruguayan shelf. This objective will be achieved using a combination of hydrological, geomorphological and geochemical data.

\section{Regional setting}

\subsection{Hydrography}

The Uruguayan shelf is characterised by a unique hydrographic system composed of water masses of contrasting thermohaline characteristics, e.g., Subantarctic Water (SAW; Sverdrup et al., 1942; Thomsen, 1962), Tropical Water and South Atlantic Central Water (TW; Emílsson, 1961; Thomsen, 1962). This also includes the influence of diluted waters defined as Coastal Water (CW), a mixture of shelf waters, mainly from the Río de la Plata estuary, the primary freshwater inflow of the area with an average discharge of 22,000 $\mathrm{m}^{3} \mathrm{~s}^{-1}$ (Framiñan and Brown 1996; Guerrero et al., 1997; Guerrero and Piola, 1997). The regional circulation system experiences a seasonal latitudinal shift in response to wind regimes (Piola et al., 2005, 2008; Möller et al., 2008; Schmid and Garzoli, 2009). At the
RESEARCH PAPER

surface, the low-salinity RdlP-BP is controlled by the dynamic of surface winds associated with the Subtropical Gyre. During the austral winter, it is shifted to NE along the inner continental shelf (extending as far as $28^{\circ}$; ; south Brazilian margin). On the other hand, the RdlP-BP remains off the mouth of the RdIP and extends along the entire upper continental margin during the austral summer, as well as during El Niño events (Piola et al., 2000, 2005; Möller et al., 2008).

On the continental shelf, below the RdlP - Buoyant Plume (RdlP-BP), southward-flowing Subtropical Shelf Water (STSW) and northward-flowing Subantarctic Shelf Water (SASW) converge at the Subtropical Shelf Front (STSF), the shelf extension of the Brazil-Malvinas Confluence (BMC; Piola et al., 2008). The STSF appears to remain latitudinally stable throughout the year, and it extends between $32^{\circ} \mathrm{S}$ at a water column depth of 50 meters and $36^{\circ} \mathrm{S}$ over the shelf break (Piola et al., 2000; Möller et al., 2008).

Another essential feature of the UCM is the occurrence of coastal upwelling events. These events occur along the estuarine and oceanic coasts and are more frequent during the summer season, when NE winds prevail (Framiñan et al. 1999; Pimenta et al. 2008; Simionato et al. 2009, 2010; Meccia et al., 2013; Trinchín et al., 2019).

\subsection{Seafloor physiography and sedimentation}

The Southwestern Atlantic Margin comprises three physiographic domains: an extensive continental shelf that widens towards the Argentinean margin (c.a. $200 \mathrm{~km}$; Urien and Ewing, 1974; Urien et al., 1980a), a steep slope and an extensive continental rise (Ewing et al., 1963; Urien and Ewing, 1974; Violante et al., 2010).

The continental shelf has a gentle slope, and the shelf break occurs at average water depths from 160 to $200 \mathrm{~m}$ (Urien and Ewing, 1974; Muñoz et al., 2010; Lantzsch et al., 2014). Whereas the outer to middle shelf display a relatively rough surface, the outermost shelf is characterised by a terrace-like shape and a smooth relief. The rough surface is the product of the differential exposure of sediments during Quaternary regressions and transgressions (Lantzsch et al., 2014). The inner shelf is characterized by an elongated seafloor depression, which represents the RdlP palaeovalley (SW-NE direction and located $40 \mathrm{~km}$ from the Uruguayan coast; Urien and Ottmann, 1971; Urien and Ewing, 1974; Urien et al., 1980a, b; López-Laborde, 1999; Cavallotto et al., 2005; Lantzsch et al., 2014). This depression was about 35 $\mathrm{km}$ wide and up to $50 \mathrm{~m}$ deep before it became partially filled by sediments from deglacial times (Lantzsch et al., 2014). To the south of this palaeovalley, the inner shelf shows remnants of barrier islands and sandbanks that constituted the major morpho-sedimentary features developed during the post-Last Glacial transgression (Urien and Ewing, 1974; Urien et al., 1980a,b; Parker et al., 2008; Violante et al., 2010). 
Also, a local Holocene sand body within the RdlP palaeovalley is described by Lantzsch et al. (2014).

Sediment distribution is closely associated with regional circulation. Pyroclastic and sandy volcanic sediments of Pampean-Patagonian origin are distributed from the Argentinean shelf and along the Uruguayan (i.e., the Río de la Plata mouth) shelf, transported northward by Subantarctic Shelf Water (SASW) (Teruggi, 1954; Etchichury and Remiro, 1960, 1963; Mahiques et al., 2008). The main sinks for the fine sediments transported along the RdlP winter buoyant plume (RdIP-BP) are the well-known mud belts that extend along the RdlP palaeovalley on the inner continental shelf
RESEARCH PAPER

(Urien, 1967; Urien and Ewing, 1974; Martins et al., 2003; Cavallotto et al., 2005; Ayup-Zouain, 2006; Lantzsch et al., 2014) and as far as the southern Brazilian margin (Mahiques et al., 2004, 2008).

This palaeovalley was infilled during deglacial sea-level rise (Lantzsch et al., 2014). At $\approx 32^{\circ} \mathrm{S}$ (over the RdlP palaeovalley on the Brazilian shelf), the deposition of modern sediment is controlled by the dynamic of the STSF (Campos et al., 2008; Nagai et al., 2013). Sandy sediments eroded from the Uruguayan basement are distributed between the coast and the RdlP palaeovalley (Urien et al., 1980a).

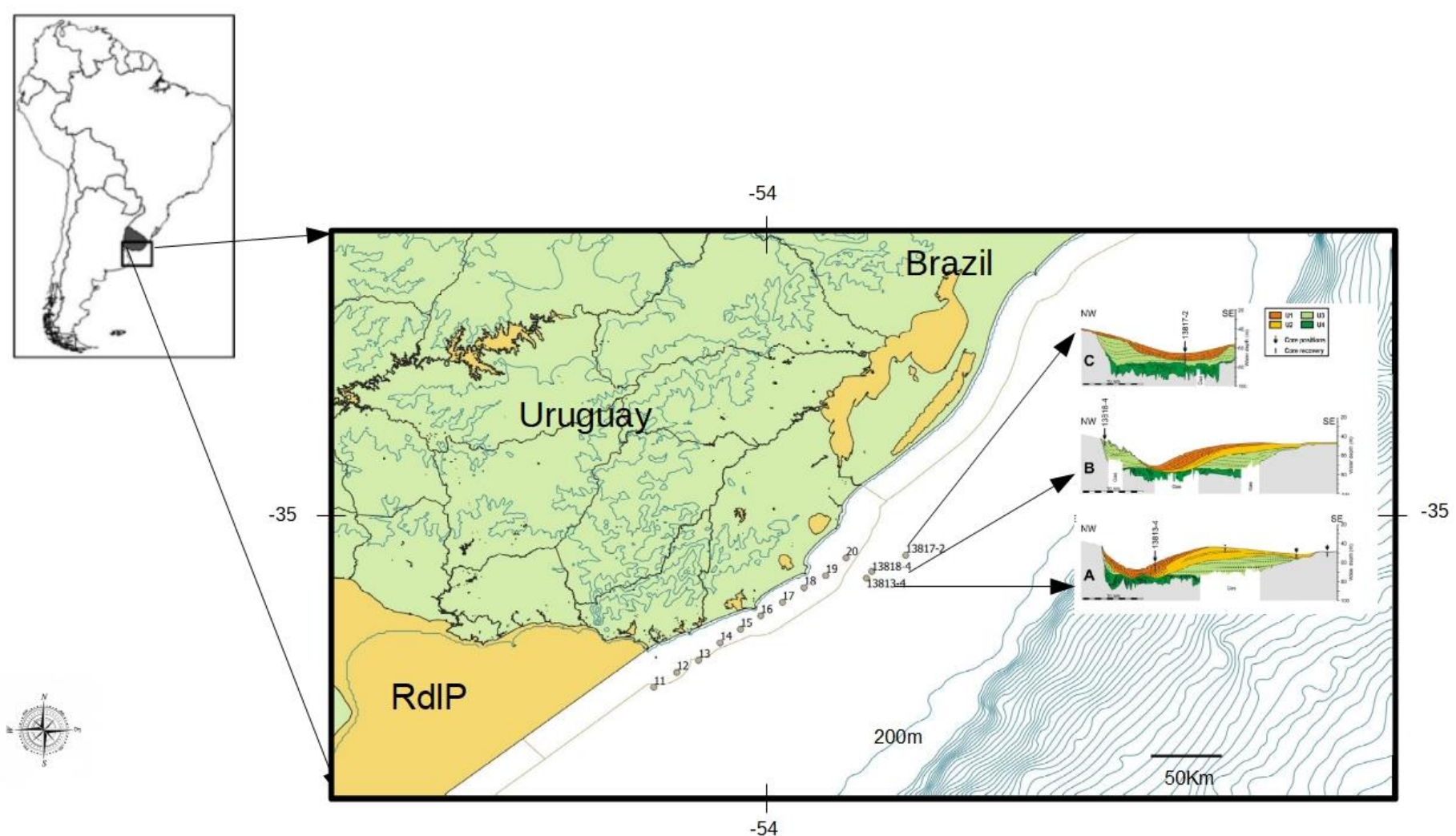

Fig. 1. Locations of the study area and sampling sites. Core positions and Parasound acoustic profiles (A, B and C) from Lantzsch et al. (2014) are shown. U4-U1: main stratigraphic units.

\section{Material and methods}

\subsection{Study area}

The study area is located on the Uruguayan inner continental shelf between longitudes $54.90^{\circ} \mathrm{W}$ to $53.48^{\circ} \mathrm{W}$ and latitudes $35.25^{\circ} \mathrm{S}$ to $34.29^{\circ} \mathrm{S}$ (Fig. 1). A ten-stations transect survey was carried out (S11 to S20) onboard the R. V. Aldebaran from Dirección Nacional de Recursos Acuáticos (DIN ARA) during the late austral autumn (11-17 May 2010). The transect presents an SW-NE orientation where each station was separated by 10 nautical miles and ranged between 25 to $37.5 \mathrm{~m}$ water depth, and the distance from the coast was between 20 and $39.2 \mathrm{~km}$ (Fig. 1).
Environmental data and sediment samples were obtained at each station. Sedimentary rock fragments sampled next to S17 were obtained by Esgemar, S.A. in July 2013 during the geophysical survey "Geophysical Study PAP".

\subsection{Environmental data}

At each station, a pressure, temperature, conductivity and fluorescence cast were performed with an SBE19plusV2 SeaCAT Profiler CTD, and depth, salinity, turbidity and chlorophyll were calculated.

Although the CTD profiler is not the ideal device for determining absolute bathymetry, it contributes to 
identifying the seafloor geomorphology based on the relative depth ranges. Seafloor geomorphology and its spatial relation with sampled stations were evaluated based on CTD results, the distance from the coast and previous geomorphological and sedimentological descriptions (Urien, 1967; Urien and Ottman, 1971; Martins, 1988, Cavallotto et al., 2005; Lantzsch et al., 2014). This correspondence was then corroborated by the present results regarding sediment texture.

\subsection{Sedimentological and geochemical data}

Sediment samples were collected using a Smith-McIntyre bottom grab sampler. In fine (sand, silt and clay) sediment samples, the following variables were analysed: grain size parameters (mean diameter and sorting), $\mathrm{C}_{\text {org }}, \mathrm{N}_{\mathrm{t}}$, bulk organic $\delta^{13} \mathrm{C}$ and $\delta^{15} \mathrm{~N}$, and major and trace elements $(\mathrm{Ba}, \mathrm{Al}$, Ti, Fe, Si, Ca, and P).

Grain size was analysed in decarbonated samples using a Malvern Mastersizer 2000 analyser. Percentages of 17 intervals ( 0.5 subclasses) were determined between 9 and -1 $\phi$. The carbonate content was determined using the weight difference before and after the acidification of $2 \mathrm{~g}$ of the sample with $10 \%$ solution of hydrochloric acid.

$\mathrm{C}_{\text {org }}, \mathrm{N}_{\mathrm{t}}, \delta^{13} \mathrm{C}$ (PDB, Pee Dee Belemnite) and $\delta^{15} \mathrm{~N}$ (Air) were determined using a Finnigan Delta V Plus coupled with a Costech Elemental Analyser at the Oceanographic Institute of the Universidade de São Paulo, Brazil. The reference materials used for the $\delta^{13} \mathrm{C}$ analysis were IA-R001 (wheat flour standard, $\delta^{13} \mathrm{Cv}-\mathrm{PDB}=-26.43 \%$ ), IAEA-CH6 (sucrose, $\delta^{13} \mathrm{CvPDB}=-10.43 \%$ ) and IA-R005 (beet sugar, $\delta^{13} \mathrm{Cv}-\mathrm{PDB}=-26.30 \%$ ). IAEA-CH-6 is an interlaboratory comparison standard distributed by the International Atomic Energy Agency (IAEA). IA-R001 and IA-R006 are calibrated against and traceable to IAEA-CH6. The reference materials, used for the $\delta 15 \mathrm{~N} \%$ analysis, were IA-R001 (wheat flour standard, $\delta^{15} \mathrm{~N}_{\text {Air }}=+2.55 \%$ ), IA-R045 (ammonium sulphate, $\delta^{15} \mathrm{~N}_{\text {Air }}=+4.71 \%$ ) and IAR046 (ammonium sulphate, $\delta^{15} \mathrm{~N}_{\text {Air }}=+22.04 \%$ ). IAR001, IA-R045 and IA-R046 are traceable to IAEA-N-1 (ammonium sulphate, $\delta^{15} \mathrm{~N}_{\text {Air }}=+0.4 \%$ ), an inter-laboratory comparison standard distributed by the IAEA.

Major and trace element concentrations of bulk sediment were analysed using X-ray fluorescence (XRF) by fused glass discs (FGD) at the Institute of Geosciences of the Universidade de São Paulo, Brazil, following the analytical procedures described in Mori et al. (1999).

In this work were used the following elemental ratios: $\mathrm{Ca} / \mathrm{Ti}, \mathrm{P} / \mathrm{Ti}, \mathrm{Ba} / \mathrm{Ti}$ and $\mathrm{Si} / \mathrm{Ti}$ (as productivity proxies; Goldberg and Arrhenius, 1958; Broecker and Peng, 1982; Dymond et al., 1992; Paytan et al., 1993; Paytan and Kastner, 1996, Mahiques et al., 2009, Burone et al., 2013). The fact that some minerals are associated with very fine sediments and others with coarse sediments determines the need to work with ratios (Yang et al., 2003; Lim et al., 2006; Francus et al., 2009). In this regard, normalising the element
RESEARCH PAPER

concentration concerning the $\mathrm{Al}$ or $\mathrm{Ti}$ concentration (celement/ cAl or $\mathrm{Ti}$ ) is a widely accepted procedure used to minimise sediment grain-size effects (Pattan et al., 1995). Al is an important component derived from the continents and has relatively low mobility during the transformation of rock to sediment. Its concentration is very similar in most of the extrusive (acidic and basic), intrusive and metamorphic rocks (Pattan et al., 1995; Tribovillard et al., 2006). However, Ti can be considered a better tracer, because $\mathrm{Al}$ is potentially more reactive to biological components and can be adsorbed in its dissolved form on the surface of carbonate particles (Murray et al., 1995; Pattan et al., 1995). Hence, the analysed elements concentrations were normalised with $\mathrm{Ti}$ concentration.

The $\mathrm{Al} / \mathrm{Si}$ and $\mathrm{Ti} / \mathrm{Al}$ ratios were $\mathrm{Ln}$ transformed for comparison with the Govin et al. (2012) data and used to assist in the origin of sediments and climatic conditions. $\mathrm{Also}, \mathrm{Al} / \mathrm{Si}$ and $\mathrm{Ti} / \mathrm{Al}$ ratios were calculated from element concentrations data from the Paraná and Uruguay rivers presented by Depetris et al. (2003) and from the Río de la Plata data presented by Burone et al. (2013). These ratios were also Ln transformed.

\subsection{Sedimentary rocks}

In some stations, rock fragments were recovered with the Smith-McIntyre bottom grab sampler together with fine sediments. These fragments were photographed and briefly described focusing on texture, reaction to hydrochloric acid for the presence of carbonate cement, and degree of consolidation.

\section{Results}

\subsection{Environmental data}

In the study area, according to the bathymetry, the seafloor presents a depression between S12 and S15, followed by a mound-like structure along stations S17 to S18 (Fig. 2). The mound-like feature height is approximately 11 meters. Station S11 is located on the inner shelf offshore from the palaeovalley, stations S12 to S16 are located in the palaeovalley central axis/inner side, stations S17 and S18 on the mound (edge of the palaeovalley), and stations S19 and S20 between the palaeovalley and the Atlantic coast.

Temperature (T) and salinity (S) profiles (Fig. 2a and b, respectively and Table 1) showed a strong vertical stratification inside the palaeovalley, associated with the influence of colder and diluted continental water on the surface ( $\mathrm{T}$ between 17.6 and $17.9^{\circ} \mathrm{C}$ and $\mathrm{S}$ between 20 and 23), with the exception of the area between S15 and S16 where warmer and saltier water outcrop ( $\mathrm{T}$ between 18.0 and $18.5^{\circ} \mathrm{C}$ and $\mathrm{S}$ between 25.0 and 25.5$)$. Higher temperatures $\left(17.9\right.$ and $19.0^{\circ} \mathrm{C}$ ) and salinities (31 and 33) values were observed at the bottom. 

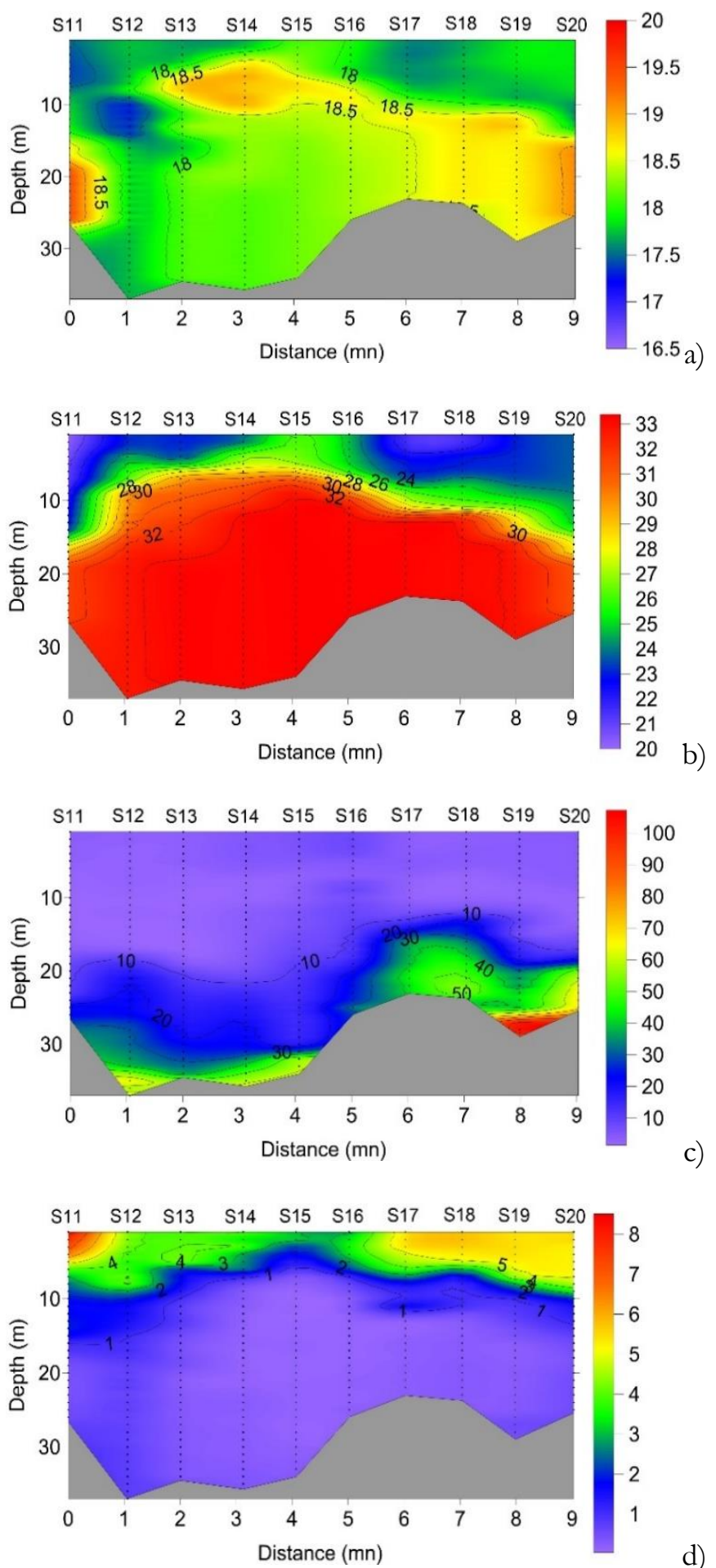

c)

Fig. 2. Vertical profiles of a) temperature $\left({ }^{\circ} \mathrm{C}\right)$; b) salinity; c) turbidity (NTU) and d) chlorophyll ( $\mu$ g.l-1). Contours and image plot are shown with a colour scale, black dots indicate where a sample was taken in each profile. Bottom axis legend: mn-nautical miles $\mathrm{x} 10$.
RESEARCH PAPER

Turbidity, between the surface and 10-20m, was under 10 NTU (NTU: Nephelometric Turbidity Unit), increasing with depth (Fig. 2C and Table 1) and displaying higher values close to the bottom, particularly at station S19 where a maximum of $\approx 100$ NTU was registered. A secondary high turbidity region is observed near the bottom of the palaeovalley (Stations S12 to S15).

Chlorophyll maxima were observed at the surface between S11 and S12 (ca. $8 \mu \mathrm{g} .1^{-1}$ ) at the outer limit of the RdlP and between S17 and S19 (ca. $5.5 \mu \mathrm{g} . \mathrm{l}^{-1}$; Fig. 2c). An area of lower surface chlorophyll (Chl) was observed between S15 and S16 (3.5 ug. $\mathrm{l}^{-1}>\mathrm{Chl}>3$ ug. $\mathrm{l}^{-1}$ ), as well as between stations 17 and $20\left(5.3\right.$ and $5.8 \mathrm{mg} / \mathrm{m}^{3}$, respectively; Figure 2D and Table 1).

\subsection{Sedimentological and geochemical data}

The frequency distribution of sediment mean in the analysed stations are shown in Fig. 3 and Table 2. Relative percentages of the main sediment size fractions are presented in Figure 4. The highest sand percentages were observed at stations S17 and S18. They are represented by very coarse sands (28.7 and $21.9 \%$, respectively) and coarse sands (20.1 and 63.8\%, respectively). Poorly and medium sorted, unimodal coarse skewed sediments characterise both stations. Station S17 was the only one showing granule contribution (34.4\%). Also, conglomerates (15 pieces of rock fragments up to $15 \mathrm{~cm}$ in diameter) were recovered in 5 sampling stations. The analysed rock fragments (from stations S16 to S20) present similar degree of consolidation, texture and biological imprints. These rocks' fragments mainly consist of cemented carbonate and moderately consolidated mudstones with coarse and very coarse sand with the presence of bioclastic material (i.e. whole and fragmented shells of bivalve and gastropod molluscs and polychaete tubes). In some cases, shells with pyrite were registered. In general, all fragments present angular shapes (see Fig. 5 a, b, c and d).

Poorly sorted, very fine sands were found in the stations S13, S14, S16 and S19. Except station 16, which showed a bimodal frequency distribution (maxima in silt and very fine sands, 21.6 and $37.9 \%$, respectively), a unimodal frequency was observed. Station S11 shows high concentrations of fine and medium sand (55.95 and 36.57\%, respectively), medium sorted, while station S19 and S20 show high heterogeneous sediment composition from coarser sand to clay with a maximum in silt (57.08\%). Also, stations S12 and S15 registered high silt percentages (51.2 and 39.4\%, respectively), poorly sorted and unimodal positive skewed. The highest clay values were related to station $15(5.3 \%)$. 

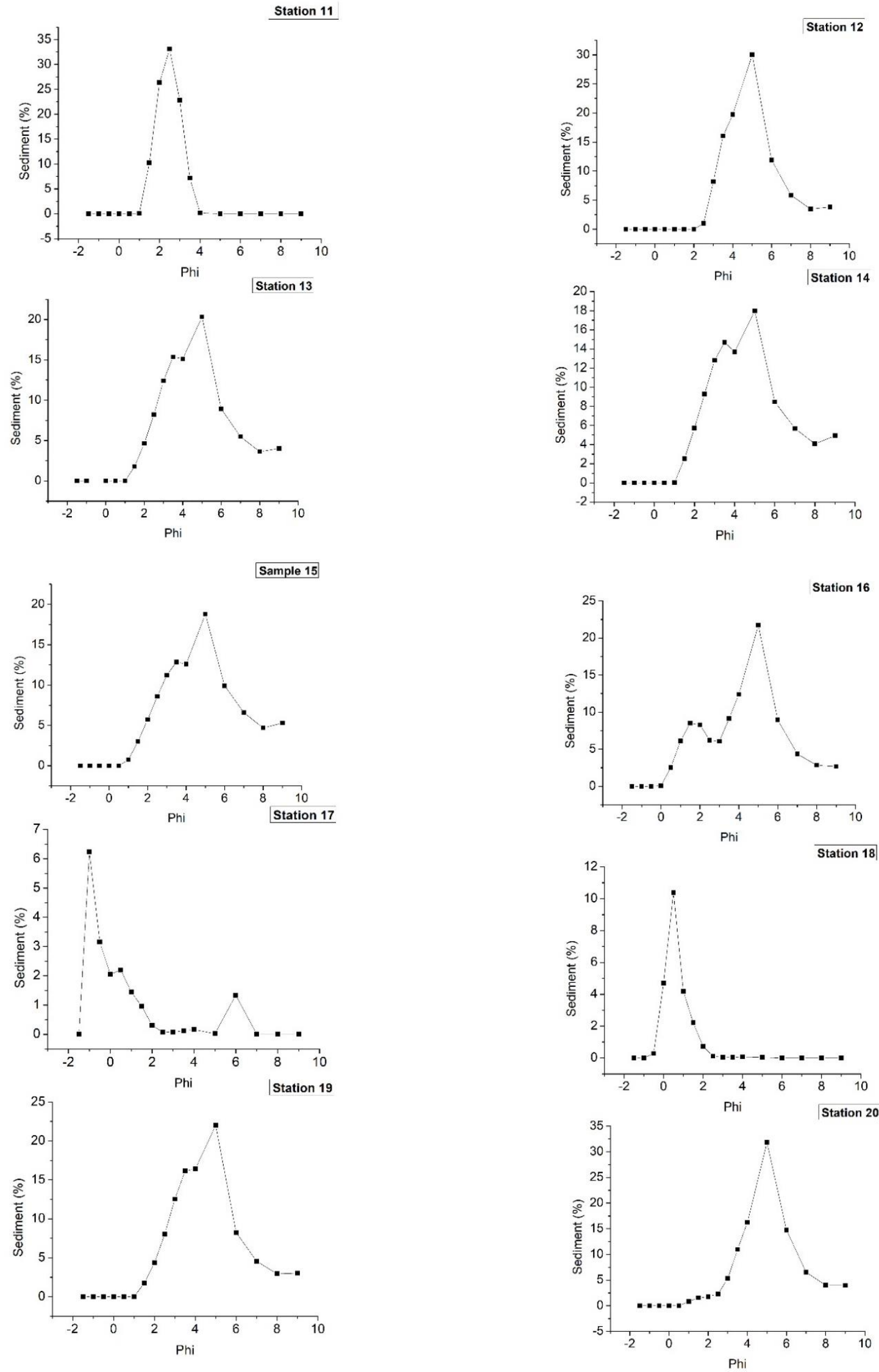

Fig. 3. Frequency distribution of sediment mean grain size. 
Tab. 1. Latitude, Longitude, depth, chlorophyll, turbidity and salinity in each station.

\begin{tabular}{|c|c|c|c|c|c|c|c|}
\hline \multirow{2}{*}{ Station } & \multirow{2}{*}{ Latitude } & \multirow{2}{*}{ Longitude } & Depth & Chlorophyll & Turbidity & Temperature & \multirow{2}{*}{ Salinity } \\
\hline & & & $(\mathrm{m})$ & $\left(\mu \mathrm{g} . \mathrm{l}^{-1}\right)$ & (NTU) & $\left({ }^{\circ} \mathrm{C}\right)$ & \\
\hline 11 & -35.2583 & -54.9033 & 26.0 & 8.505 & 22.461 & 19.508 & 31.648 \\
\hline 12 & -35.1500 & -54.7333 & 37.5 & 4.084 & 62.458 & 17.705 & 32.813 \\
\hline 13 & -35.0500 & -54.5833 & 34.0 & 3.993 & .033 .111 & 18.131 & 33.307 \\
\hline 14 & -34.9333 & -54.4167 & 34.0 & 4.093 & 58.337 & 18.092 & 33.216 \\
\hline 15 & -34.8333 & -54.2667 & 33.5 & 3.009 & 58.725 & 18.203 & 33.355 \\
\hline 16 & -34.7333 & -54.1167 & 25.5 & 2.786 & 33.525 & 18.339 & 33.323 \\
\hline 17 & -34.6166 & -53.9500 & 23.0 & 5.575 & 41.345 & 18.453 & 33.282 \\
\hline 18 & -34.5166 & -53.8000 & 25.8 & 5.751 & 55.399 & 18.697 & 33.091 \\
\hline 19 & -34.4166 & -53.6333 & 28.0 & 5.342 & 104.773 & 18.586 & 32.916 \\
\hline 20 & -34.3000 & -53.4833 & 28.0 & 5.447 & 67.825 & 19.127 & 31.218 \\
\hline
\end{tabular}

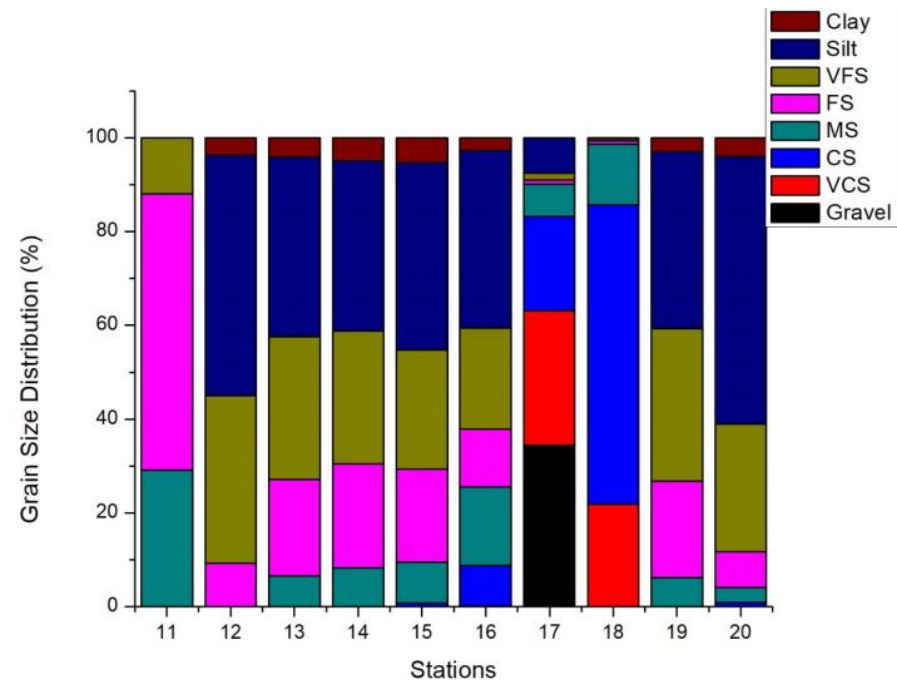

Fig. 4. Relative percentages of the main sediment size fractions in the studied stations. Gravel; VCS = very coarse sand; CS = coarse sand; MS = medium sand; FS = fine sand; VFS = very fine sand

Values of the productivity proxies $(\mathrm{Si} / \mathrm{Ti}, \mathrm{Ba} / \mathrm{Ti}, \mathrm{Ca} / \mathrm{Ti}$ and $\mathrm{P} / \mathrm{Ti}$ ) ranged between 48.5 and 1265.6 for $\mathrm{Si} / \mathrm{Ti}, 1.4$ and 300.5 for $\mathrm{Ca} / \mathrm{Ti}$, and 0.08 and 0.88 for P/Ti (Fig. 6; Table2). These proxies presented the highest values between stations S16 and S19, except station S18.

$\mathrm{C}_{\text {org }}$ and $\mathrm{N}_{\mathrm{t}}$ concentrations ranged between 0.55 and $1.20 \%$ and 0.04 and $0.16 \%$, respectively (Table 2). The maximum $\mathrm{C}_{\text {org }}$ and $\mathrm{N}_{\mathrm{t}}$ concentration were registered at station S12. $C_{\text {org }}$ values from S16 and S18 to S20 were not available since they fall below the detection limit of the equipment. $\mathrm{N}_{\mathrm{t}}$ values data was not available only for station $\mathrm{S} 18$.

The proxies used to infer organic matter origin are presented in Table 2 . The $\mathrm{C} / \mathrm{N}$ ratio showed a gradually decreasing trend from station $\mathrm{S} 12$ to $\mathrm{S} 15$ (values between 7.29 and 4.33). Carbon and nitrogen stable isotope values showed similar trends, increasing from S12 to S15 in the case of the $\delta^{13} \mathrm{C}$, and from S12 to S20 for the $\delta^{15} \mathrm{~N}$. The $\delta^{13} \mathrm{C}$ showed the minimum value at $\mathrm{S} 15$. For $\delta^{13} \mathrm{C}$, values from S16 to S20 were below the detection limit.

With regard to proxies used to assist in the origin of sediments and climatic conditions - $\mathrm{Ln}(\mathrm{Ti} / \mathrm{Al})$ and $\mathrm{Ln}(\mathrm{Al} / \mathrm{Si})$ - average values for stations $\mathrm{S} 12$ to $\mathrm{S} 15$ were $\mathrm{Ln}$ $=-2.8658 ; \mathrm{Ln}=-1.9509$, respectively, for stations S16, S17 and S18, $\mathrm{Ln}=-3.4409 ; \mathrm{Ln}=-3.3136$, respectively, for S11, $\mathrm{Ln}=-2.73$ and $\mathrm{Ln}=-2.53$, respectively and for S19 and S20 $\operatorname{Ln}=-2.3323 ; \mathrm{Ln}=-2.2006$, respectively.

\section{Discussion}

The Uruguayan inner continental shelf is characterised by three main sedimentary environments (Urien et al., 1980a b; Martins et al., 2003) associated with: I) "Atlantic coastal sands" (i.e. onshore from the palaeovalley); II) the SW-NE running "RdlP palaeovalley" and; III) "Relict sands" (i.e., offshore of the RdIP palaeovalley). Recently, Lantzsch et al. (2014) described three exposed sedimentary units (U1 to U3) from acoustic profiles and sediment cores (sedimentary characteristics of stratigraphic units) almost entirely restricted to the palaeovalley. The present transect intersects these three main environments contributing thus with the description of the morphological setting and sedimentary coverture, as well as with an integrated environmental analysis and geochemical imprint of sedimentary facies.

The sedimentary environment named as "Atlantic coastal sands" (i.e. onshore from the palaeovalley) is characterised by sands eroded from the Uruguayan basement and includes relicts of ancient shorelines (Urien et al., 1980a). However, the morphology and distribution of these ancient shorelines are not characterised along the inner shelf nor does the transition towards the RdlP 
a)

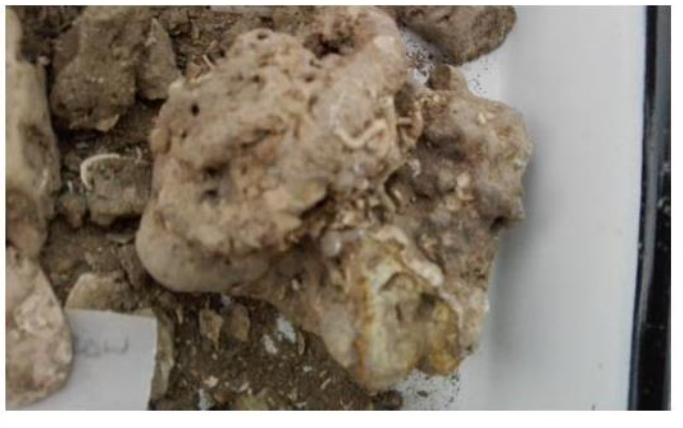

c)

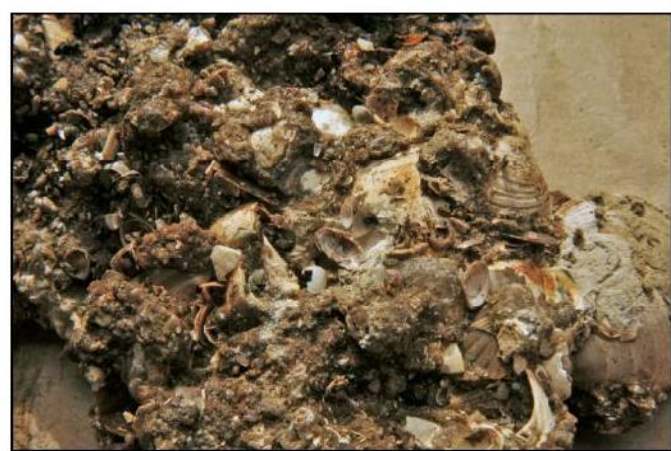

b)

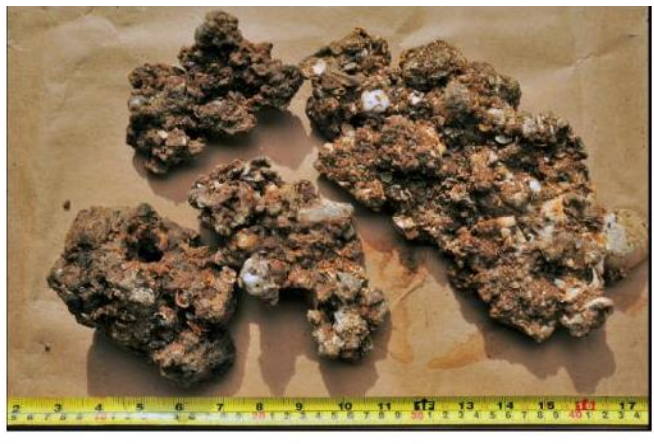

d)

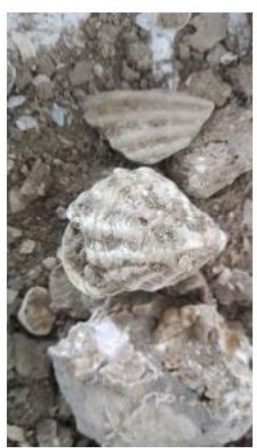

Fig. 5. Rock and shell fragments: a- recovered from station S16; b- and c- from station S17 and; d- from station S19.

Tab. 2. Organic carbon $\left(\mathrm{C}_{\mathrm{org}}\right)$, total nitrogen $(\mathrm{Nt})$, carbon nitrogen ratio $(\mathrm{C} / \mathrm{N})$, carbon $(\delta 13 \mathrm{C})$ and nitrogen $(\delta 15 \mathrm{~N})$ isotopes, elements sediment size fractions (VCS: very coarse sand, CS: coarse sand, MS: medium).

\begin{tabular}{|c|c|c|c|c|c|c|c|c|c|c|c|}
\hline Station & Unities & 11 & 12 & 13 & 14 & 15 & 16 & 17 & 18 & 19 & 20 \\
\hline $\mathrm{C}_{\text {org }}$ & $(\%)$ & - & 1.196 & 1.118 & 1.046 & 0.871 & - & 0.267 & - & - & - \\
\hline $\mathbf{N}_{\mathrm{t}}$ & $(\%)$ & - & 0.165 & 0.148 & 0.149 & 0.127 & 0.047 & 0.076 & - & 0.094 & 0.042 \\
\hline $\mathrm{C} / \mathrm{N}$ & & - & 7.24 & 7.55 & 7.02 & 6.85 & - & 3.51 & - & - & - \\
\hline$\delta^{13} \mathrm{C}$ & $(\% 0)$ & - & -20.943 & -21.031 & -20.852 & -20.513 & - & -5.166 & - & - & - \\
\hline$\delta^{14} \mathbf{N}$ & $(\% 0)$ & 0.43 & 6.34 & 5.826 & 5.282 & 4.852 & 1.845 & 6.674 & - & 6.331 & 0.714 \\
\hline $\mathrm{Al}$ & $(\mathrm{mg} / \mathrm{Kg})$ & 2.691 & 4.244 & 4.53 & 4.305 & 3.87 & 1.05 & 1.122 & 1.177 & 2.074 & 1.404 \\
\hline $\mathrm{Ti}$ & $(\mathrm{mg} / \mathrm{K})$ & 0.175 & 0.502 & 0.513 & 0.506 & 0.4534 & 0.114 & 0.044 & 0.03 & 0.215 & 0.282 \\
\hline $\mathrm{Ba} / \mathrm{Ti}$ & & 2288.4 & 588.6 & 428.7 & 504.0 & 789.6 & 1968.5 & 10102.9 & 15708.9 & 1358.6 & 728.9 \\
\hline $\mathrm{Fe} / \mathrm{Ti}$ & & 3.497 & 4.623 & 4.949 & 4.908 & 4.817 & 7.393 & 12.931 & 8.695 & 5.282 & 3.106 \\
\hline $\mathrm{Si} / \mathrm{Ti}$ & & 193.754 & 51.766 & 48.509 & 48.709 & 60.607 & 168.399 & 581.680 & 1265.627 & 133.653 & 105.584 \\
\hline $\mathrm{Ca} / \mathrm{Ti}$ & & 24.339 & 3.059 & 1.393 & 1.540 & 2.331 & 168.753 & 300.528 & 92.824 & 31.489 & 32.435 \\
\hline $\mathrm{P} / \mathrm{Ti}$ & & 0.108 & 0.078 & 0.076 & 0.085 & 0.082 & 0.877 & 0.669 & 0.357 & 0.127 & 0.446 \\
\hline Granule & $(\%)$ & 0 & 0 & 0 & 0 & 0 & 0 & 34.36 & 0 & 0 & 0 \\
\hline VCS & $(\%)$ & 0 & 0 & 0 & 0 & 0 & 0.08 & 28.74 & 21.86 & 0 & 0 \\
\hline CS & $(\%)$ & 0.09 & 0 & 0.01 & 0.03 & 0.75 & 8.66 & 20.07 & 63.86 & 0.02 & 0.8 \\
\hline MS & $(\%)$ & 36.57 & 0 & 6.45 & 8.27 & 8.73 & 16.81 & 6.95 & 12.92 & 6.08 & 3.31 \\
\hline FS & $(\%)$ & 55.95 & 9.19 & 20.63 & 22.12 & 19.82 & 12.28 & 0.88 & 0.71 & 20.59 & 7.63 \\
\hline VFS & $(\%)$ & 7.39 & 35.78 & 30.5 & 28.42 & 25.43 & 21.56 & 1.49 & 0.49 & 32.57 & 27.21 \\
\hline Silt & $(\%)$ & 0 & 51.21 & 38.37 & 36.22 & 39.98 & 37.92 & 7.5 & 0.18 & 37.73 & 57.08 \\
\hline Clay & $(\%)$ & 0 & 3.82 & 4.02 & 4.93 & 5.29 & 2.68 & 0 & 0 & 3.01 & 3.96 \\
\hline Mean diam. & $\phi$ & 2.2 & 4.38 & 3.98 & 3.98 & 4.09 & 3.44 & -0.19 & 0.39 & 3.87 & 4.48 \\
\hline Sorting & & MS & PS & PS & PS & PS & PS & PS & MS & PS & PS \\
\hline
\end{tabular}


paleovalley. In this work, the bathymetrical profile allows characterising a mound-like feature at the onshore edge of the RdlP palaeovalley $\left(53.45^{\prime} \mathrm{W}, 34.62^{\prime} \mathrm{S}\right.$ and $53.79^{\prime} \mathrm{W}$, 34.51 'S). Its textural composition, mixture of moderately consolidated mudstones with coarse and very coarse sand as well as with the presence of bioclastic material, is similar to the sedimentary characteristics of the Unit 3 as described by Lantzsch et al. (2014). According to these authors, this unit deposition ranges from 13.7 and $9.7 \mathrm{cal} \mathrm{ka} \mathrm{BP}$, is located below modern units (U1 and U2) in the palaeovalley axis and is exposed near the palaeovalley edge. These characteristics and the presence of consolidated biogenic rock fragments collected in both sides of the mound-like structure suggests that it could represent an ancient coastline.

The sedimentary environment "RdlP palaeovalley" (45 $\mathrm{km}$ wide and $50 \mathrm{~m}$ deep; Lantzsch et al., 2014), is distributed along the inner continental shelf and is covered by Unit 1 . This unit is described as almost entirely restricted to the SWNE running palaeovalley and represents a relatively modern shelf mud depocenter which is composed essentially of silt. According to these authors, its mud accumulation in this environment started at about $1.5 \mathrm{cal} \mathrm{ka}$ BP. In the present work, five stations are located in this sedimentary environment.

Offshore of the RdlP palaeovalley the "Relict sands" characterised the continental shelf (80 to $90 \%$ fine sands, well and medium sorted). These sands coming from the Argentinean margin and were deposited during the Pleistocene and reworked during the Holocene transgression (Urien et al., 1980a, b; Martins et al., 2003). One sample in this work (S11) represents this facies.

\subsection{Environmental description}

Precipitation and wind pattern determine the physicochemical conditions of the water column in the study area (Ortega and Martínez, 2007; Möller et al., 2008; Piola et al., 2008). The strong vertical stratification observed is related to the influence of colder and diluted continental water from the RdlP on the surface, and warmer and saltier oceanic shelf waters at the bottom product of the still fall presence shelf waters advected by the $\mathrm{BC}$ during the austral warm season. This thermal inversion is typical of this region at de beginning of the cold austral season when halinestratification determines that the surface freshwater layer loses heat rapidly (Martínez and Ortega, 2015; Piola et al., 2018). However, this stratification may be favoured by the palaeovalley geomorphology.

The circulation in this region is primarily driven by the alongshore component of wind stress, which generates a positive sea-level coastal anomaly, a geostrophically balanced northward-flowing coastal jet during fall and winter, and downwelling of sea-level associated with southward coastal flow during spring and summer (Saraceno et al., 2004). In
RESEARCH PAPER

this regard, the summer SST climatology favoured an upwelling phenomenon $\left(\mathrm{SST}<22^{\circ} \mathrm{C}\right)$ affecting stations $\mathrm{S} 15$ to S18. This correlates to the coastal bands of negative sea surface temperature anomalies observed along the southern coast of Uruguay and indicators of upwelling associated with strong easterly and northeasterly winds (e.g., Palma et al., 2008; Pimenta et al., 2008; Simionato et al., 2010, Trinchín et al., 2019).

These events are also evident as bands of low coastal sealevel in satellite-derived sea surface height anomalies and tide gauge data (Saraceno et al., 2014). These jet-related upwellings could, in turn, affect the geochemical composition of the seafloor.

Apart from the wind-driven upwelling process, other physical mechanisms can promote or even produce upwelling events (i.e., topography; Kämpf and Chapman, 2016). In the present work, the observed outcrop of warmer and saltier water, is probably related to the geomorphology of the palaeovalley (i.e., stations 17 and 18 located on the edge of the palaeovalley). The bottom and subsurface warm and salty water is a product of admixture of shelf waters during the austral warm season when higher advection of $\mathrm{BC}$ occurs. In this regard, the mound-like feature could induce bottom water to rise, operating as a ramp. This upwelling could enhance the jet-related upwelling discussed above. In this regard, productivity proxies $(\mathrm{Si} / \mathrm{Ti}, \mathrm{Ba} / \mathrm{Ti}, \mathrm{Ca} / \mathrm{Ti}$ and P/Ti; Murray et al., 1995; Wei et al., 2003; Mahiques et al., 2009; Pérez et al., 2018) present the highest values in stations S17 and S18 (palaeovalley edge - ancient coast). They are higher than those registered in the RdlP (Burone et al., 2013) and the outer shelf and upper and middle Uruguayan slope (Franco-Fraguas et al., 2016), showing values several orders of magnitude higher.

Turbidity displayed the highest value close to the bottom, particularly at S19, where a maximum of about 100 NTU was registered. Generally, turbidity is related to high-velocity currents and no sediment bypass or erosion (Anfuso et al., 2003). However, it should be noted that station S19 is located on a steep slope in the onshore side of the moundlike feature. This geomorphological feature together with an intense current parallel to the coast likely increases current velocities and, in consequence, leads to erosive processes on the edge of the palaeovalley as indicated by the coarse sand and gravel composition, promoting highest turbidity conditions at S19 (Anfuso et al., 2003). Additionally, turbidity inside the palaeovalley should be associated with a slow sedimentation process (organic and inorganic particles). The mound-like feature, the turbidity and sediment distribution (see below) evidences and corroborates that the palaeovalley acts as a natural barrier against the shelf currents promoting high sedimentation rates (Pérez et al., 2018).

Chlorophyll maxima were observed at the surface between S11 and S12 (ca. $8 \mu \mathrm{g} . \mathrm{l}^{-1}$ ) at the outer limit of the RdIP and between S17 and S18 (ca. $5.5 \mu \mathrm{g} .1^{1-1}$ ) at the edge of the palaeovalley. In the case of stations S11 and S12, high chl 
values match with the lowest registered turbidity. Burone et al. (2013) found values of chl $\left(6.5 \mu \mathrm{g} \cdot \mathrm{l}^{-1}\right)$ in the RdlP immediately offshore of the turbidity front. In this study, stations $\mathrm{S} 11$ and $\mathrm{S} 12$ receive a significant contribution of nutrients from the RdlP and do not present turbidity. It is known that phytoplankton shows a positive reaction to
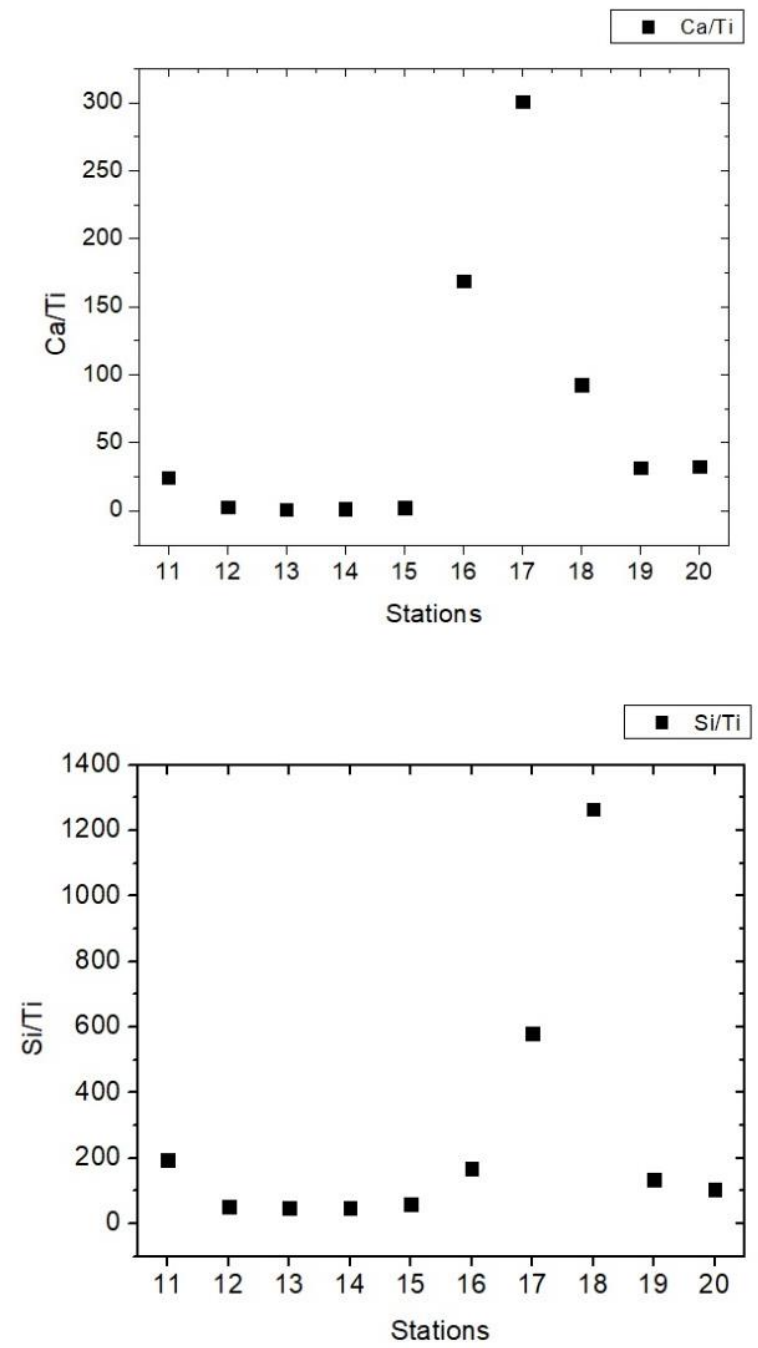

Fig. 6. Productivity proxies' ratios: $\mathrm{Si} / \mathrm{Ti}, \mathrm{Ba} / \mathrm{Ti}, \mathrm{Ca} / \mathrm{Ti}$ and $\mathrm{P} / \mathrm{Ti}$.

\subsection{Sedimentary environment}

\subsubsection{Palaeovalley}

Among stations located in the palaeovalley (central axis/inner side), the high percentages of fine sediments indicate the RdlP as principal sediment source (Urien, 1967; Urien and Ottman, 1971; Urien et al., 1980a, b; Martins and Villwock, 1987; Martins et al., 2003). Sediment from stations S12 and S15 present high percentages of silt and unimodal distribution. Stations S13 and S14 are characterised by very fine sands and by unimodal distribution (S13 and S14), with maxima in very fine sand. All of them are poorly sorted and were interpreted as resulting from the reworking and remobilisation of previously deposited sediments (Martins et al., 2003). It is important to point out that station S16 is
RESEARCH PAPER

nutrient enrichment. High nutrient supply promotes the growth of large-sized phytoplankton, and this is reflected in high chl concentrations (Acha et al., 2015). High chl values, observed in stations S17 and S18 could be a consequence of the effect of the upwellings registered there.
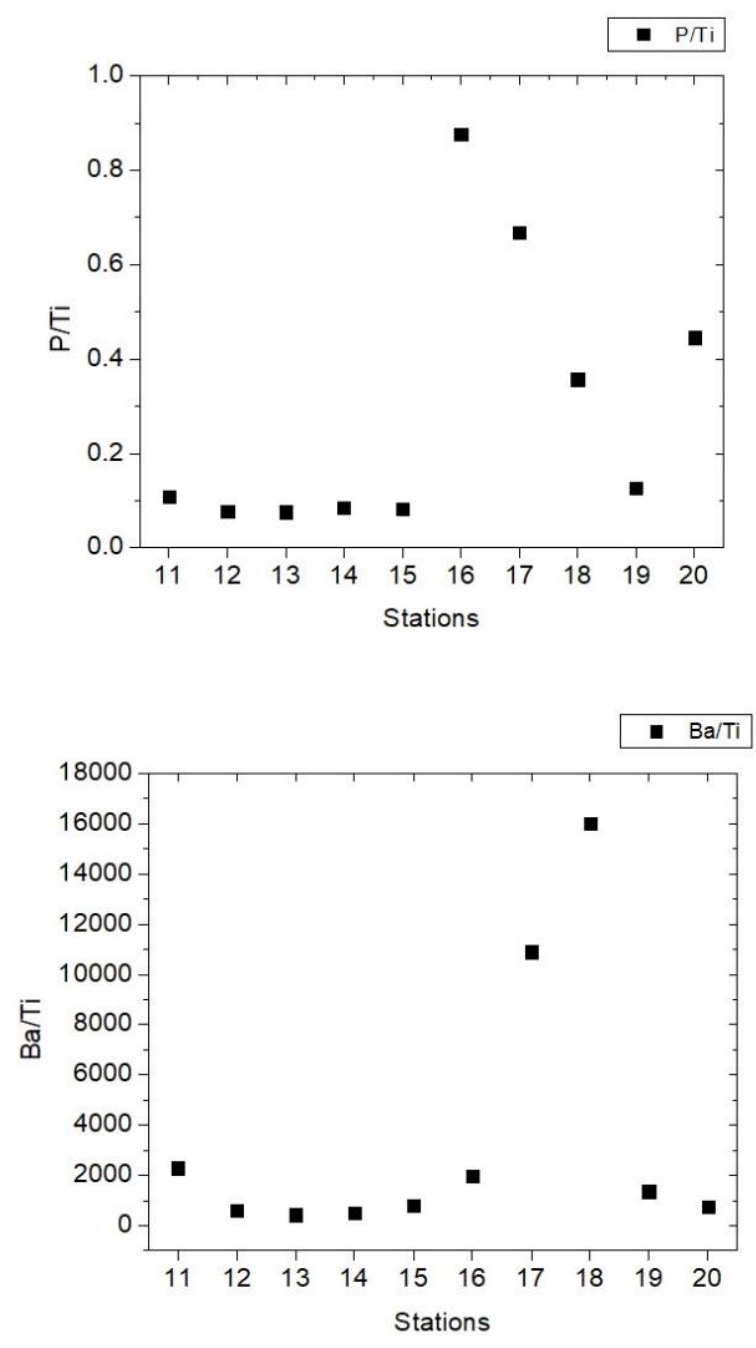

characterised by fine sand but shows bimodal distribution indicating more than one source of sediment.

Following the units described by Lantzsch et al. (2014) and the sedimentary characteristics of these sediments, samples S12 to S15 depict Unit 1. This unit, as previously mentioned, is restricted to the SW-NE running palaeovalley and represents a relatively modern shelf mud depocenter which is composed principally of silt. According to Lantzsch et al. (2014), its mud accumulation started at around $1.5 \mathrm{cal}$ $\mathrm{ka} \mathrm{BP}$ and continues in the present, and $\mathrm{Nd}$-isotope data indicates the "Plata Province" as a sediment source. The fact that the stations here studied also show contribution of very fine sand and fine sand may be related with the proximity to the palaeovalley edge and the contribution of eroded sediments (e.g., from U3; ancient coast) towards the 
palaeovalley. It is essential to highlight that rocks and shelf fragments were recovered in station S16 and onshore of the palaeovalley (see below). Also, the bimodal sediment distribution observed in stations S16 (located at a water depth of $25.5 \mathrm{~m}$ ) lower than those stations located southward (S12-S15; depths between 37 and $33.5 \mathrm{~m}$ ) may support this hypothesis (see Fig. 4 in Lantzsch et al., 2014).

As expected, stations located in the palaeovalley register relatively high $\mathrm{C}_{\mathrm{org}}$ concentration (values between 0.5 and 1.2 $\%$ ). These values are similar to those registered by Burone et al. (2013) in the RdlP, especially in stations affected by the turbidity front position. Fine-grained mineral and organic particles are characterised by a similar settling mechanism (Tyson, 1995). Stable carbon and nitrogen isotope values $\left(\delta^{13} \mathrm{C}\right.$ and $\left.\delta^{15} \mathrm{~N}\right)$, as well as $\mathrm{C} / \mathrm{N}$ ratio, show a decreasing gradient from $\mathrm{S} 12$ to $\mathrm{S} 16$, indicating more terrestrial influence in S12 due to its proximity to the RdlP.

The $\mathrm{Ln}(\mathrm{Al} / \mathrm{Si})$ shows the same value $(-1.951)$ than for the RdlP (Burone et al., 2013; -1.95) but it is lower than the value registered by Govin et al. (2012) along the South American margin between $24^{\circ} \mathrm{S}-35^{\circ} \mathrm{S}$ (-1.16). Low $\mathrm{Al} / \mathrm{Si}$ values are related to drier regions and correspond to the elemental composition of RdlP suspended matter described by Depetris and Griffin (1968) and Depetris et al. (2003). The difference observed between $\mathrm{Ln}(\mathrm{Al} / \mathrm{Si})$ values from Govin et al. (2012) and the present work may be related to the high proportion of skeletons of diatom in sediment here registered. Nevertheless, Pérez et al. (2018) studied a core from the RdlP and observed low correlation between $\mathrm{Si} / \mathrm{Al}$ element ratio and biogenic Si. In the future, samples with appreciable biogenous $\mathrm{Si}$, must be corrected using direct measures of opal (Calvert and Pedersen, 2007).

$\mathrm{Ln}(\mathrm{Ti} / \mathrm{Al})$ value $(-2.86)$ corresponds to the average value from the RdlP (-2.82; Burone et al., 2013) and is similar to the value presented by Govin et al. (2012) for the RdlP suspended matter from South Brazil and Uruguayan margin $\left(24^{\circ} \mathrm{S}-36^{\circ} \mathrm{S} ;-2.74\right)$. Moreover, this value is in agreement with the Paraná river mean value (-2.831; Depetris et al., 2003). According to Govin et al. (2012), the $\mathrm{Ln}(\mathrm{Ti} / \mathrm{Al})$ ratio of the RdlP sediments remain higher than those of Senegal, Niger, Congo and Amazon rivers because it carries the signature of young Andean volcanic rocks rich in Ti oxides, with some influence of lowland Jurassic-Cretaceous tholeiitic basalts (Depetris et al., 2003; Govin et al., 2012). Suspended sediment from RdlP mostly derives from the mountainous drainage basin of the Bermejo river and the other Andean tributaries (Depetris et al., 2003).

\subsubsection{Palaeovalley edge}

On the edge of the palaeovalley (stations S17 and S18), S17 is the only one (of the whole samples here studied) that shows a contribution of granules. Both of them (S17 and S18) are represented by very coarse and coarse sands, poorly
RESEARCH PAPER

to moderately sorted, unimodal and positively skewed sediments. These stations are representatives of a sandy facies (quartz and bioclasts: whole and fragment shells and polychaetes tubes) with a biodetritic pattern. Also, rocks were recovered in these stations. Sediment textural proprieties of these stations, as well as the lowest $C_{\text {org }}$ values concentration (including values below the limit of detection), reflect the high energy of the shelf currents, which cause high erosion and prevent fine sediment and organic matter deposition in this geological feature (ancient coast) (Ortega and Martínez, 2007). Facies with these characteristics are recognized in the Uruguayan continental margin (on the shelf) and associated with transgressions and marine stabilization during deglacial sea-level rise (Urien et al., 1980b; Martins and Villwock, 1987; Corrêa et al., 1992; Martins et al., 2003; Lantzsch et al., 2014).

These results correspond to data from sediment cores recovered from the RdlP palaeovalley (Lantzsch et al., 2014). U3 outcrops in the surface and sediment shows rhythmic mud lamination, intercalations of fine sands with abundant cross-bedding, and small-scale erosive channels in the central axis, while deposits from a marginal position within the palaeovalley (edge) varied from pure mud to molluscfragment gravel.

According to Lantzsch et al. (2014), U3 was one of the main depocenters for the RdlP fine sediments during the deglacial period. Also, during the sea-level rise, a significant contribution of sandy material from the Argentine margin up to about 5 cal. ka BP was registered (Corrêa et al., 1992; Mahiques et al., 2009; Nagai et al., 2009; Lantzsch et al., 2014). According to the water column depth in which the palaeovalley edge (23-25 $\mathrm{m}$ deep) is located, this would correspond to the third sea-level stabilisation at $6.5 \mathrm{cal}$. ka BP, between 20 and $25 \mathrm{~m}$ occurring during the Upper Pleistocene and Holocene for the South Western Atlantic (Urien and Ewing, 1974; Martins, 1978; Urien et al., 1980b; Corrêa and Baitelli, 1981; Urien and Martins, 1989; Corrêa et al., 1992; Martins et al., 2003). During this period, the most significant coastal deposits were formed by the remobilisation of transgressive sands, and the palaeovalley was flooded.

The low $\mathrm{Ln}(\mathrm{Al} / \mathrm{Si})$ value (-3.31) may be a consequence of the colder and drier conditions prevailing in the region during the formation of this facies (Nagai et al., 2009; Govin et al., 2012; Lantzsch et al., 2014). Also, biogenic Si and quartzose sands (predominant in these samples) may influence this value (these stations are characterised by high productivity as a consequence of the described upwelling). A mixture between sediment provenance of the Argentina margin and the RdlP may also occur.

Low $\mathrm{Ln}(\mathrm{Ti} / \mathrm{Al})$ value $(-3.440)$ probably indicates weaker chemical weathering as a consequence of the colder climate prevailing during the period of this facies formation (Razik et al., 2015). 


\subsubsection{Onshore paleovalley}

The onshore area of the palaeovalley (stations S19 and S20) encompasses poorly sorted very fine sand and coarser silt. Also, rocks and shells fragments were recovered from these stations. These were the most heterogeneous sediment recovered in this work. These rocks and biogenic material probably come from the palaeovalley edge (ancient coast) due to erosion by shelf currents (as mentioned before). Additionally, the fine material (silt and clay) present in these stations may suggest that U1 extends outside the palaeovalley to the coast. Evidence of it may be observed in the Parasound acoustic profile (Figure 4c; Lantzsch et al., 2014). In this regard, this area could be a mixture of different sedimentary facies (sediment from U1 and U3 and also contribution of Coastal Atlantic sands may be considered).

There are no values for $\mathrm{C}_{\text {org }}$ and isotope $\left(\delta^{13} \mathrm{C}\right.$ and $\left.\delta^{15} \mathrm{~N}\right)$ because they were below the limit of detection. Productivity proxies ( $\mathrm{Si} / \mathrm{Ti}, \mathrm{Ba} / \mathrm{Ti}, \mathrm{Ca} / \mathrm{Ti}$ and $\mathrm{P} / \mathrm{Ti}$ ) show low values indicating low marine productivity.

The $\mathrm{Ln}(\mathrm{Al} / \mathrm{Si})$ values for stations S19 and S20 (-2.62 and -3.05 , respectively) are quite lower than the value shown by Govin et al. (2012; -1.16) to the South American margin between $24^{\circ} \mathrm{S}$ and $35^{\circ} \mathrm{S}$. These differences may result from the different sources of sediments in this region $(\mathrm{U} 1, \mathrm{U} 3$ and coastal sands).

$\mathrm{Ln}(\mathrm{Ti} / \mathrm{Al})$ value (-2.73) correspond to the value described by Govin et al. (2012) along the South American margin between $24 \circ \mathrm{S}$ and $38^{\circ} \mathrm{S}$ (-2.73). Precipitation that falls over southern Brazil and Uruguay within the drainage basin of the Plata River is directed to the RdlP mouth, together with the relatively high load of suspended sediments (ca. $36^{\circ} \mathrm{S}$ ) (e.g., Depetris et al., 2003). According to Govin et al. (2012) suspended sediments from the RdlP mostly derive from the mountainous drainage basin of the Bermejo River and other Andean tributaries. They carry the signature of young Andean volcanic rocks rich in Ti oxides, with some influence of the lowland Jurassic-Cretaceous tholeiithic basalts (Depetris et al., 2003). This feature explains why $\mathrm{Ti} / \mathrm{Al}$ values in surface sediments off South Brazil and Uruguay are relatively high compared to those of other major rivers (Congo and Amazon Rivers).

\subsubsection{Offshore palaeovalley}

Relict sands (offshore of the palaeovalley) are represented only by one station (S11). Station S11 textural composition (medium sorted fine sand) reflects the highenergy hydrodynamic that characterises the shelf (Urien et al., 1980a, b). Like onshore palaeovalley there are no values for $\mathrm{C}_{\text {org }}$ and isotope $\left(\delta^{13} \mathrm{C}\right.$ and $\left.\delta^{15} \mathrm{~N}\right)$ because they were below the limit of detection. Also, productivity proxies ( $\mathrm{Si} / \mathrm{Ti}$, $\mathrm{Ba} / \mathrm{Ti}, \mathrm{Ca} / \mathrm{Ti}$ and $\mathrm{P} / \mathrm{Ti}$ ) show low values indicating low marine productivity. The $\mathrm{Ln}(\mathrm{Al} / \mathrm{Si})$ value $(-2.53)$ is lower than the value shown by Govin et al. $(2012$; -1.16$)$ to the South American margin between $24 \circ$ and $35^{\circ} \mathrm{S}$. Again, the high contribution of quartzose sand may affect the ratio.

\section{Final considerations}

The integration of hydrological, morphological and sedimentological data of the study area allowed the characterisation of the sediment imprint of the hydrological setting influencing the Uruguayan inner shelf environment as well as the geological inheritance in the sediment. These characteristics are summarised in Fig. 7.

In this regard, the sediment geochemical proxies allowed an accurate characterisation of sediments representing units (U1 and U3) previously identified in the study area. Also, sedimentary and hydrodynamic processes acting in the area were discussed. An upwelling is described in the area probably related to the edge of the palaeovalley. In this sense, it is proposed that this feature, together with the winds (NE winds in summer season) can promote the bottom water rise, operating as a ramp. Results highlight a strong morphologic and past and present hydrodynamic control on sedimentation.

This upwelling affects the geochemical composition of the seafloor as documented by the highest values of bioproductivity proxies.

Sediments from U1 show the terrestrial imprint of the RdlP, while sediments that characterised U3 indicate a sandy facies (quartz and bioclasts: whole and fragmented shells and polychaetes tube with a biodetritic pattern) corresponding to an ancient coast. This last of approximately $11 \mathrm{~m}$ height), is probably related to the sea-level stabilisation, between 20 and $25 \mathrm{~m}$ occurring during the Upper Pleistocene and Holocene for the South-Western Atlantic. The sediment from U3 reflects the colder and drier conditions (in comparation with $\mathrm{U} 1$ that is related to warmer and more wet conditions; Corrêa et al., 1992) prevailing in the region during the formation of this facies (13.7 and $9.7 \mathrm{cal} \mathrm{ka} \mathrm{BP})$.

Eroded sediments (e.g., from U3; ancient coast) are deposited inside the palaeovalley and on the onshore region (between palaeovalley and coast sands). Also, U1 extends from the palaeovalley covering the onshore region. The information reported in this paper is particularly important to better understand the sediment dynamics on the Uruguayan inner shelf and the South-Western Atlantic region. It is also important for elaborating more precise paleoenvironmental and palaeoceanographic reconstructions. 


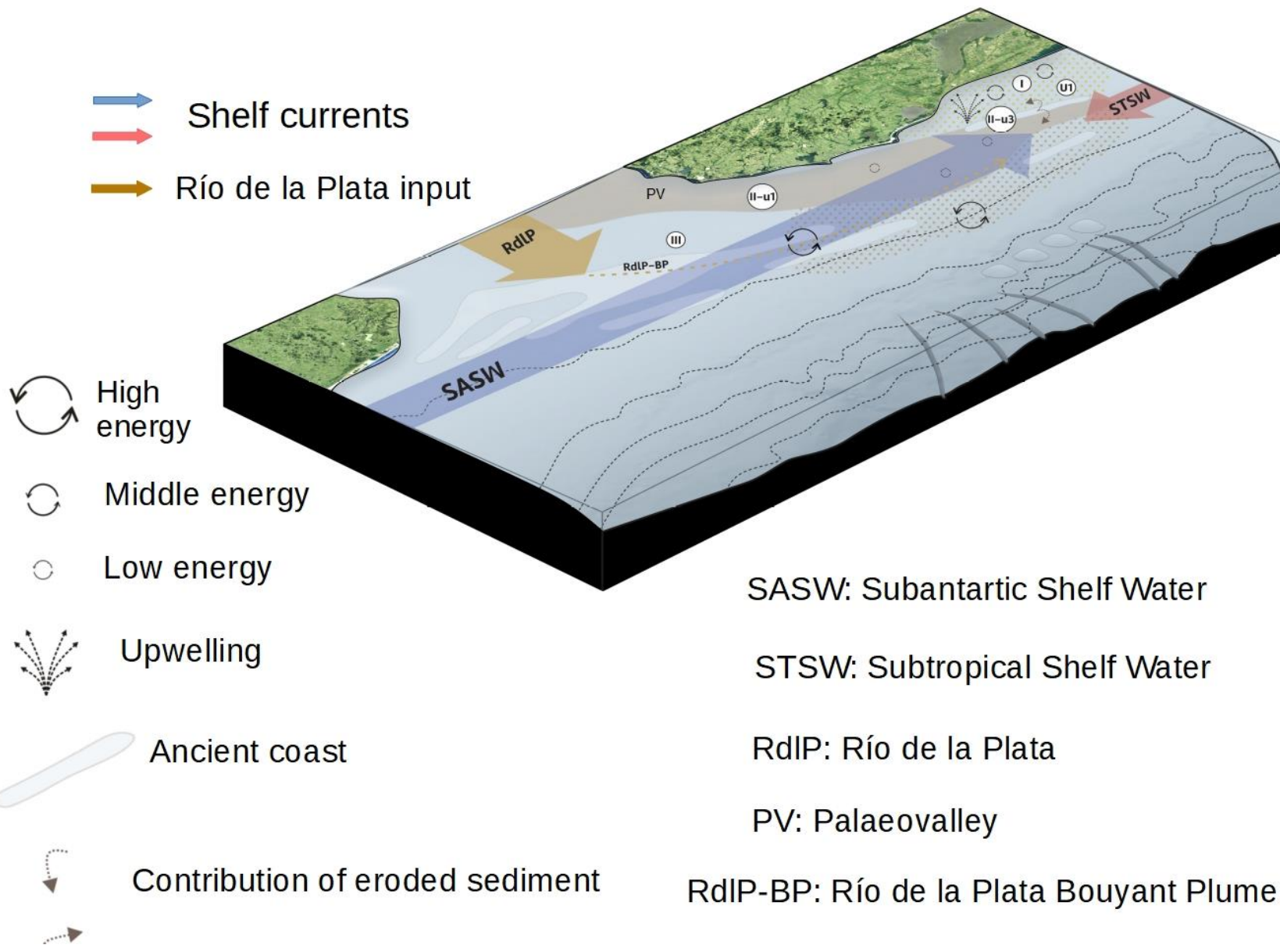

Fig. 7. Schematic diagram showing the sediment dynamics and sedimentary processes associated to the regional hydrology and geomorphology. The relative intensity of the sedimentary process is indicated by the size of the respective markers. I) "Atlantic coastal sands" (onshore from the palaeovalley); II) the SW-NE running "RdlP palaeovalley", and III) "Relict sands". U1: unit 1; U3: unit 3.

\section{Acknowledgements}

The oceanographic cruise was funded and supported by the Dirección Nacional de Recursos Acuáticos (DINARA). We want to thank Mr Michaell Hellmer for improving English. Guillermo Burone is acknowledged for the synthetic diagram. This paper is contribution N. ${ }^{\circ} 4$ by the Grupo de Investigación en Ciencia y Tecnología Marina (CINCYTEMA).

\section{References}

Acha, E. M., Piola, A., Iribarne, O., Mianzan, H., 2015. Ecological Processes at Marine Fronts. Oases in the 352 Ocean. Springer, 68P https://doi.org/10.1007/978-3-319-15479-4

Abreu, J.G.N., Neto, D.G., 1998. Distribuição dos sedimentos superficiais na plataforma continental interna do litoral norte de Santa Catarina. Terra, 1978-1979.

Anfuso, G., Martínez, J.A., Sánchez, F., Benavente, J., LópezAguayo, F., 2003. Morphodynamics of swashbars in mesotidal exposed beaches of SW Spain. Ciencias Marinas 29(1), 35-50.

Ayup-Zouain, R.N., 2006. Evolución paleogeográfica y dispersión de los sedimentos del Río de la Plata. In: Menafra, R., Rodriguez-Gallego, L., Scarabino, F., Conde, D. (Eds.), Bases para la Conservación y el Manejo de la Costa Uruguaya. Vida Silvestre Uruguay, Montevideo, pp. 1-8.

Biscaye, P.E., 1965. Mineralogy and sedimentation of recent deepsea clay in the Atlantic Ocean and adjacent seas and oceans, Geological Society of America Bulletin 76(7),803832,doi:10.1130/0016-7606(1965)76[803:MASORD]2.0.CO;2 Broecker, W.S., Peng, T.-H., 1982. Tracers in the Sea. LamontDoherty Earth Observatory, Palisades N.Y.

Burone, L., Franco-Fraguas, P., Mahiques, M., Ortega, L., 2018. Geomophological and sedimentological characterization of the Uruguaian Continental Margin: A review and state of the art. Journal of Sedimentary Environments 3(4), 253-264. https://doi.org/10.12957/jse.2018.39150

Burone, L., Centurión, V., Cibils, L., Franco-Fraguas, P., GarcíaRodríguez, F., García, G., Pérez, L., 2014 Sedimentología y Paleoceanografía. In: Uruguay, Mar Territorial/Programa oceanográfico de caracterización del margen continental de la Republica Oriental del Uruguay, ANCAP, Facultad de Ciencias, Montevideo, pp. 54 -56.

Burone, L., Ortega, L., Franco-Fraguas, P., Mahiques, M., GarcíaRodríguez, F., Venturini, N., Marin, Y., Brugnoli, E., Nagai, R., Muniz, P., Bícego, M., Figueiras, R., Salaroli, A., 2013. A multiproxy study along the transition between the Río de la 
Plata and the adjacent Southwestern Atlantic inner Shelf to assess the sediment footprint of river vs. marine influence. Continental Shelf Research 55, 141-154. https://doi.org/10.1016/j.csr.2013.01.003.

Calvert, S., Pedersen, T.F., 2007. Chapter Fourteen Elemental Proxies for Palaeoclimatic and Palaeoceanographic Variability in Marine Sediments: Interpretation and Application. 2007. Developments in Marine Geology 1, 567-644. https://doi.org/10.1016/S1572-5480(07)01019-6

Campos, E.J.D., Mulkerherjee, S., Piola, A.R., de Carvalho, F.M.S., 2008. A note on a mineralogical analysis of the sediments associated with the Plata River and Patos Lagoon outflows. Continental Shelf Research 28, 1687-1691. https://doi.org/10.1016/j.csr.2008.03.014

Cavallotto, J.L., Violante, R., Colombo, F., 2005. Evolución y cambios ambientales de la llanura costera de la cabecera del río de la Plata. Revista de la Asociación Geológica Argentina 60(2), 353-367.

Cazes-Boezio, G., Robertson, A.W., Mechoso, C.R., 2003. Seasonal dependence of enso teleconnections over South America and relationships with precipitation in Uruguay. Journal of Climate 16 (8), 1159-1176.

Corrêa, I.C.S., 1996. Les variations du niveau de la mer durant les derniers 17.500 ans BP: l'exemple de la plate-forme continentale du Rio Grande do Sul-Brésil. Marine Geology 130, 163-178.

Corrêa, I.C.S., Baitelli, R., Ketzer, M.J., Martins, R., 1992. Translação horizontal e vertical do nível do mar sobre a plataforma continental do Rio Grande do Sul nos últimos 17.550 anos BP. Anais III Congresso ABEQUA-Belo Horizonte, 225-240 pp.

Corrêa, I.C.S., Baitelli, R., 1981. Sea level relative variations on Rio Frande do Sul continental shelf-Brazil. In: Zinternational Congress INQUA. 13. Beijing-China. Abstracts, 66p.

Depetris, P.J., Probst, J.L., Pasquini, A.I., Gaiero, D.M., 2003. The geochemical characteristics of the Paraná River suspended sediment load: an initial assessment. Hydrological Processes 17, 1267- 1277. https://doi.org/10.1002/hyp.1283.

Depetris, P.J., Griffin, J.J., 1968. Suspended load in the Río de la Plata drainage basin. Sedimentology. 11 (1-2), 53-60. https://doi.org/10.1111/j.1365-3091.1968.tb00840.x

Díaz, A.F., Studzinski, C.D., Mechoso, C.R., 1998. Relationships between precipitation anomalies in Uruguay and Southern Brazil and sea surface temperature in the Pacific and Atlantic Oceans. Journal of Cimate251-271.

Dymond, J.R., Suess, F., Lyle, M., 1992. Barium in deep-sea sediment: a geochemical proxy for paleoproductivity. Paleoceanography 7, 163-181.

Emílsson, I., 1961. The shelf and coastal waters off southern brazil. Boletim do Instituto Oceanográfico da Universidade de São Paulo 11, 101-112.

Etchichury, M.C., Remiro, J., 1963. La corriente de Malvinas y los sedimentos pampeano-patagónicos. Rev. Museo Argentino Bernardino Rivadavia. Cs. Geológicas. Tomo I- n²0.

Etchichury, M.C., Remiro, J.R., 1960. Muestras de fondo de la plataforma continental comprendida entre los paralelos $34^{\circ}$ y $36^{\circ} 30$ de latitud sur y los meridianos $53^{\circ} 10$ y $56^{\circ} 30$ de longitud oeste. VI Revista del Museo Argentino de Ciencias Naturales, Bernardino Rivadavia 4, 1-70.
RESEARCH PAPER

Ewing, M., Ludwig, W.J., Rwing, J.I., 1963. Geophysical investigations in the submerged Argentine coastal plain. Geological Society of America Bulletin 74, 275-295.

Framiñan, M.B., Etala, M.P., Acha, E.M., Guerrero, R. A., Lasta, C.A., Brown, O.B., 1999. Physical Characteristics and Processes of the Río de la Plata estuary. In: Perillo, G.M.E. Piccolo M.C. and Pino-Quivira, M., Eds., Estuaries of South America: Their Geomorphology and Dynamics, Springer Verlag, 161-194.

Framiñan, M.B., Brown, O.B., 1996. Study of the Río de la Plata turbidity front part I: spatial and temporal distribution. Cont. Shelf Res. 16, 1259-1282.

Franco-Fraguas, P., Burone, L., Mahiques, M., Ortega, L., Carranza, A., 2016. Modern sedimentary dynamics in the Southwestern Atlantic Contouritic Depositional System: New insights from the Uruguayan margin based on a geochemical approach. Marine Geology 376, 15-25. https://doi.org/10.1016/j.margeo.2016.03.008.

Francus, P., Lamb, H., Nakawaga, T., Marshall, M., Brown, E., 2009. The potential of high resolution $X$-ray fluorescence core scanning: Applications in paleolimnology, PAGES news, 17, 9, 93-95.

Goldberg, E., Arrhenius, G., 1958. Chemistry of pelagic sediments. Geochimica et Cosmochimica Acta 13, 153-212.

Govin, A., Holzwarth, U., Heslop, D., Keeling, L.F., Zabel M., Mulitza, S., Collins, J.A., Chiessi, C.M., 2012. Distribution of major elements in Atlantic surface sediments $\left(36^{\circ} \mathrm{N}-49^{\circ} \mathrm{S}\right)$ : Imprint of terrigenous supply and continental weathering. Geochemistry, Geophysics, Geosystems 13(1),1525-2027. https://doi.org/10.1029/2011GC003785.

Guerrero, R.A., Piola, A.R., 1997. Masas de agua en la Plataforma Continental. In: Boschi, E.E. (ed), El Mar Argentino y sus Recursos Pesqueros. Tomo 1. Antecedentes históricos de las exploraciones en el mar y las características ambientales. Mar del Plata, Argentina: Instituto Nacional de Investigación y Desarrollo Pesquero, 107-118pp.

Guerrero, R.A., Piola, A.R., Boschi, E.E., 1997. Masas de agua en la plataforma continental. El Mar Argentino y sus Recursos Pesqueros. Instituto Nacional de Investigación y Desarrollo Pesquero (INIDEP), Mar del Plata. A. R. 1, pp. 107-118.

Guilderson, T.P., Burckle, L., Hemming, S., Peltier, W.R., 2000. Late Pleistocene sea level variation derived from the Argentine Shelf. Geochemistry Geophysics Geosystems 1(12), 10551070.

Gyllencreutz, R., Mahiques, M.M., Alves, D.V.P., Wainer, I.K.C., 2010. Mid- to late-Holocene paleoceanographic changes on the southeastern Brazilian shelf based on grain size records. The Holocene 20, 863-875.

Kämpf, J., Chapman, P., 2016. Upwelling Systems of the World. Cham: Springer International Publishing, https://doi.org/10.1007/978-3-319-42524-5

Lantzsch, H., Hanebuth, T.J.J., Chiessi, C.M., Schwenk, T., Violante, R.A., 2014. The high-supply, current-dominated continental margin of southeastern South America during the late Quaternary. Quaternary Research 81, 339-354. https://doi.org/10.1016/j.yqres.2014.01.003.

Lim, D.I., Jung, H.S., Choi, J.Y., Yang, S., Ahn, K.S., 2006. Geochemical compositions of river and shelf sediments in the Yellow Sea: grain-size normalization and sediment provenance. Continental Shelf Research 26, 15-24. 
López-Laborde, J., 1999. Sand deposits on the outer shelf of the Río de la Plata and adjacent continental shelf. Non living resources of the Southern Brazilian Coastal Zone and Continental Margin OAS/IOC-UNESCO/MCT. Special Publication. L.R. Martins, Santana, C.I. Porto Alegre, Brasil, 80-91.

Mahiques, M.M., Wainer, I.E.K.C., Burone, L., Sousa, S.H.M., Silveira, I.C.A., Bícego, M.C., Alves, D.P., Hammer, O., 2009. A high-resolution Holocene record on the Southern Brazilian shelf: paleoenvironmental implications. Quaternary International 206, 52-61.

Mahiques, M.M., Gaeta Tassinari, C.C., Marcolini, S., Violante, R.A., Lopes Figueira, R.C., Almeida da Silveira, I.C., Burone, L., Sousa, S.H.M., 2008. Nd and Pb isotopes signatures on the southeastern south America upper margin: implication for sediment transport and source rocks. Marine Geology 250, 51 63. https://doi.org/10.1016/j.margeo.2007.11.007

Mahiques, M.M., Tessler, M.G., Ciotti, A.M., da Silveira, C.A., de Mello e Souza, S.H., Figueira, R.C.L., Tassinari, C.C.G., Furtado, V.V., Passos, R.F., 2004. Hydrodynamically driven patterns of recent sedimentation in the shelf and upper slope off Southeast Brazil. Continental Shelf Research 24, 16851697.

Mahiques, M.M., Mishima, Y. and Rodrigues, M., 1999. Characteristics of the Sedimentary Organic Matter on the Inner and Middle Continental Shelf between Guanabara Bay and Sao Francisco do Sul, Southeastern Brazilian Margin. Continental Shelf Research, 19, 775-798. http://dx.doi.org/10.1016/S0278-4343(98)00105-8

Martin, J.-M., Meybeck, M., 1979. Elemental mass-balance of material carried by major world rivers. Marine Chemistry 7 , 173-206.

Martins, L.R., Urien, C.M., Martins, I.R., 2005. Gênese dos sedimentos da plataforma continental Atlântica entre o Rio Grande do Sul (Brasil) e Tierra del Fuego (Argentina). Gravel $5,85-102$.

Martins, L.R., Martins, I.R., 2004. Presença de turfa na Plataforma Continental do Rio Grande do Sul. Gravel 2: 77-85.

Martins, L.R., Martins, I.R., Urien, C.M., 2003. Aspectos sedimentares da plataforma continental na área de influencia de Río de la Plata. Gravel 1, 68-80.

Martins, L.R., 1988. Conhecimento atual da geologia costeira e marinha da região sul da América Latina. Informe UNESCO sobre Ciencias del Mar 47, 1-21.

Martins, L.R., Villwock, J.A., 1987. Eastern South America Quaternary Coastal and Marine Geology: a synthesis UNESCO Reports in Marine Sciences (43) 28-96. Paris. França.

Martínez, A., Ortega, L. 2015. Delimitation of domains in the external Río de la Plata estuary, involving phytoplanktonic and hydrographic variables. Brazilian Journal of Oceanography[online]. 2015, vol.63, n.3, pp.217-227. ISSN 1679-8759.http://dx.doi.org/10.1590/S167987592015086106303.

Meccia, V.L., Simionato, C.G., Guerrero, R.A., 2013. The Río de la Plata Estuary Response to wind variability in synoptic timescale: salinity fields and salt wedge structure. Journal of Coastal Research. 29(1), 61-67.

Möller Jr., O.O., Piola, A.R., Freitas, A.C., Campos, E.J.D., 2008. The effects of river discharge and seasonal winds on the shelf
RESEARCH PAPER

off southeastern South America. Continental Shelf Research 28, 1607-1624.

Mori, P.E., Reeves, S.H., Correia, C.T., Haukka, M., 1999. Development of a fused glass disc XRF facility and comparison with the pressed powder pellet thechnique at Instituto de Geociências, Universidade de São Paulo. Revista Brasileira de Geociências 29 (3), 441-446.

Muñoz, A., Fontan, A., Marín, Y., Carranza, A., Franco-Fraguas, P., Rubio, L., 2010. Informe de Campaña Uruguay 0110. Buque de Investigación Oceanográfica y Pesquera Miguel Oliver (SCM).

Murray, R.W., Leinen, M., Murray, D.W., Mix, A.C., Knowlto, C.W., 1995. Terrigenous Fe input and biogenic sedimentation in the glacial and interglacial equatorial Pacific Ocean. Glob. Geochem. Cycles 9, 667-684.

Murray-Wallace, C.V., Woodroffe, C.D. 2014. Quaternary sea level changes: A global perspective. Cambridge University Press, 504 pp.

Muto, T., Still, R.J., 1997 Principles of regression and transgression: The nature of the interplay between accommodation and sediment supply. Journal of Sedimentary Research 67:6, 994-1000. http://dx.doi.org/10.1306/D42686A8-2B26-11D78648000102C1865D

Nagai, R.H., Ferrerira, P.A.L., Mulkherjee, S., Martins,V.M., Figueira, R.C.L., Sousa, S.H.M., Mahiques, M.M., 2013. Hydrodynamic controls on the distribution of surface sediments from the southeast South American continental shelf between $23^{\circ} \mathrm{S}$ and $38^{\circ} \mathrm{S}$. Continental Shelf Research. http://dx.doi.org/10.1016/j.csr.2013.09.016.

Nagai, R.H., Sousa, S.H.M., Burone, L., Mahiques, M.M., 2009. Paleoproductivity changes during the Holocene in the inner shelf of Cabo Frio, southeastern Brazilian continental margin: Benthic foraminifera and sedimentological proxies. Quaternary International 206, 62-71.

Ortega, L., Martínez, A., 2007. Multiannual and Seasonal Variability of Water Masses and Fronts Over the Uruguayan shelf. Journal of Coastal Research 23, 618-629. https://doi.org/10.2112/04-0221.1

Palma, E.D., Matano, R.P., Piola, A.R., 2008. A numerical study of the Southwestern Atlantic Shelf circulation: stratified ocean response to local and offshore forcing. Journal of Geophysical Research 113, 1-22.

Parker, G., Violante, R.A., Paterlini, C.M., Costa, I.P., Marcolini, S.I., Cavallotto, J.L., 2008. Las secuencias depositacionales del plioceno-cuaternario en la plataforma submarina adyacente al litoral del este bonaerense. Latin American Journal of Sedimentology and Basin Analysis 15(2), 105-124.

Pattan, J.N., Rao Ch, M., Higgs, N.C., Colley, S., Parthiban, G., 1995. Distribution of major, trace and rare earth elements in surface sediments of the Wharton Basin, Indian Ocean. Chemical Geology 121, 201-216.

Paytan, A., Kastner, M., Martin, E.E., MacDougall, J.D., Herbert, T., 1993. Marine barite as a monitor of seawater strontium isotope composition. Nature 366, 445-449.

Paytan, A., Kastner, M., 1996. Benthic Ba fluxes in the central Equatorial Pacific, implications for the oceanic Ba cycle. Earth and Planetary Science Letters 142, 439-450.

Pérez, L., Crisci, C., Hanebouth, T.J.J., Lantzsch, H., Perea, G., Rodríguez, M. A., Pérez, A., Fornaro, L., García-Rodríguez, F., 
2018. Climatic oscillations modulating the Late Holocene fluvial discharge and terrigenous material supply from the Río de la Plata into the Southwestern Atlantic Ocean. Journal of Sedimentary Environments 3(4), 205-219.

Pisciottano, G., Díaz, A., Cazess, G., Mechoso, C.R., 1994. El niño-southern oscillation impact on rainfall in Uruguay. Journal of Climate 7 (8), 1286-1302,

Pimenta, F., Garvine, R., Münchow, A., 2008. Observations of coastal upwelling off Uruguay downshelf of the Plata estuary, South America. Journal of Marine Research 66(6), 835-872pp.

Piola, A.R., Campos, E.J.D., Möller, J.O., Charo, M., Martinez, C., 2000. Subtropical shelf front off Eastern South America. Journal of Geophysical Research 105, 6565-6578.

Piola, A.R., M.J., O.O., Guerrero, R.A., Campos, E.J.D., 2008. Variability of the Subtropical Shelf Front off eastern South America: winter 2003 and summer 2004. Continental Shelf Reseach 28, 1579-1588.

Piola, A.R., Matano, R.P., Palma, E.D., Moller, Jr.O.O., Campos E.J.D., 2005. The influence of the Plata River discharge on the western South Atlantic shelf. Geophysical Research Letters 32, L01603. https://doi.org/10.1029/2004GL021638

Piola, A.R., Palma, E.D., Bianchi, A.A., Castro, B.M., Dottori, M., Guerrero, R.A., Marrari, M., Matano, R.P., Möller Jr., O.O., Saraceno, M., 2018. Physical oceanography of the SW Atlantic shelf: a review. In: Hoffmeyer, M.S. (Ed.), Plankton Ecology of the Southwestern Atlantic, https://doi.org/10.1007/978-3319-77869-3-2.

Prahl, F.G., Ertel, J.R., Goni, M.A., Sparrow, M.A., Eversmeyer, B., 1994. Terrestrial organic carbon contributions to sediments on the Washington margin. Geochimica et Cosmochimica Acta 58, 3035-3048.

Razik, S., Govin, A., Chiessi, C.M., Dobeneck, T.V., 2015. Depositional provinces, dispersal, and origin of terrigenous sediments along the SE South American continental margin. Marine Geology 363, 261-272.

Saraceno, M., Provost, C., Piola, A.R., Bava, J., Gagliardini, A., 2004. Brazil Malvinas Frontal System as seen from 9 years of advanced very high resolution radiometer data. Journal of Geophysical Research, 109, 1-14.

Schmid, C., Garzoli, L., 2009. New observations of the spreading and variability of the Antarctic Intermediate Water in the Atlantic. Journal of Marine Research 67(6), 815-843. https://doi.org/10.1357/002224009792006151.

Schütz L., Rahn K.A., 1982. Trace-element concentrations in erodible soils. Atmos Environ 16(1):171-176.

Shumilin, E.N., Carriquiry, J.D., Camacho-Ibar, V.F., Sapozhnikov, D., Kalmykov, S., Sanchez, A., Aguíniga-García, S., Sapozhnikov, Y.A., 2002. Spatial and vertical distributions of element in sediments of the Colorado River delta and Upper Gulf of California. Marine Chemistry 79, 113-131.

Simionato, C.G., Tejedor, M.L., Camptella, C., Guerrero, R., Moreira, D., 2010. Patterns of sea surface temperature variability on seasonal to sub-annual scales at and offshore the Río de la Plata estuary. Continental Shelf Research 30(19), 1983-1997.

Simionato, C. G., Meccia, V.L., Dragani, W.C., 2009. On the path of plumes of the Rio de la Plata Estuary main tributaries and their mixing scales. Geoacta 34(2), 87-116.

Shiller, A.M., 1982. The geochemistry of particulate major elements in Santa Barbara Basin and observations on the
RESEARCH PAPER

calcium carbonate-carbon dioxide system in the ocean, $\mathrm{PhD}$ thesis, 197 pp., Univ. of California, San Diego.

Strub, T., Mesias, J., Montecino, V., Rutllant, J., Salinas, S., 1998. Coastal Ocean Circulation over South America, The Sea, Vol. 11. edited by Allan R. Robinson and Kenett H Brink; John Wiley \& Sons Inc., New York.

Sverdrup, H.U., Johnson, M., Fleming, R., 1942. The Oceans. Their Physics, Chemistry and General Biology. Prentice Hall, New York.

Teruggi, M.E., 1954. El material volcánico-piroclástico en la sedimentación pampeana. AAS Revista 9, 184-191.

Thomsen, H., 1962. Masas de agua características del Océano Atlántico (parte Sudoeste). Buenos Aires: Servicio de Hidrografía Naval, Secretaría Marina, Publication H632 pp. 127.

Tribovillard, N., Algeo, T. J., Lyons, T., Riboulleau, A., 2006. Trace metals as paleoredox and paleoproductivity proxies: An update. Chemical Geology 232, 12-32.

Trinchín, R., Ortega, L., Barreiro, M., 2019. Spatiotemporal charecterization of summer coastal upwelling events in Uruguay, South America. Regional Studies in Marine Science 31, 100787.

Tyson, R.V., 1995. Sedimentary Organic Matter. Organic Facies and Palynofacies.

Urien, C.M., Martins, L.R. 1989. Southern Brazil, Uruguay and Argentina: Late Pleistocene events modelling a sequential stratigraphic analysis. International Symposium on Global Changes in South America during the Quaternary: past, present, future. ABEQUA Special Publication 1, 197-208, São Paulo, Brazil.

Urien, C.M., Martins, L.R. 1987. Basal transgressive sand markers of Holocene marine transgression. INQUA International Congress Abstracts: 279, Ottawa, Canada.

Urien, C.M., Martins, L.R., Martins, I.R., 1980a. Evolução geológica do Quaternário do litoral atlântico uruguaio, plataforma continental e regiões vizinhas.Notas Técnicas 3, 743.

Urien, C.M., Martins, L.R., Martins, I.R., 1980b. Modelos deposicionais na plataforma continental do Rio Grande do Sul (Brasil), Uruguai e Buenos Aires. Notas Técnicas 3, 13-25.

Urien, C.M., Ewing, M., 1974. Recent sediments and environment of Southern Brazil, Uruguay, Buenos Aires, and Rio Negro continental shelf. In: Burk, C., Drake, C.H. (Eds.), The Geology of Continental Margins. Springer-Verlag, New York, pp. 157-177.

Urien, C.M., Ottmann, F., 1971. Histoire du Río de la Plata au Quaternaire. "Quaternaria” XIV, Roma.

Urien, C.M., 1967. Los sedimentos modernos del Río de la Plata. Boletin SHIN 4 (2), 113-213.

Violante, R. A., Paterlini, C. M., Costa, I. P., Hernández-Molina, F. J., Segovia, L. M., Cavallotto, J.L., Marcolini, S., S., Bozzano, G., Laprida, C., García Chapori, N., Bickert, T., Spiess, V., 2010. Sismoestarigrafía y evolución geomorfológica del talud continental adyacente al litoral del este bonaerense, Argentina. Latin American Journal of Sedimentology and Basin Analysis 17 (1), 33-62.

Wei, G., Liu, Y., Li, X., Chen, M., Wei, W., 2003. High-resolution elemental records from the South China Sea and their paleoproductivity implications. Paleoceanography, 18, http://dx.doi.org/10.1029/2002PA000826. 
Weltje, G.J., Tjallingii, R., 2008. Calibration of XRF core scanners for quantitative geochemical logging of sediment cores: theory and application. Earth Planet Science Letter 274, 423-438. https://doi.org/10.1016/j.epsl.2008.07.054

Yang, S., Youn, J., 2007. Geochemical compositions and provenance discrimination of the central south Yellow Sea
RESEARCH PAPER sediments. Marine Geology 243, 229-241. https://doi.org/10.1016/j.margeo.2007.05.001

Yang, S.Y., Jung, H.S., Lim, D.I., Li, C.X., 2003. A review on the provenance discrimination of the Yellow Sea sediments. Earth-
Science
Reviews
63
(12),
93-120.

https://doi.org/10.1016/S0012-8252(03)00033-3 